\title{
Technical and economic feasibility of organic Rankine cycle-based waste heat recovery systems on feeder ships: Impact of nitrogen oxides emission abatement technologies
}

Baldasso, Enrico; Andreasen, Jesper Graa; Mondejar, Maria E.; Larsen, Ulrik; Haglind, Fredrik

Published in:

Energy Conversion and Management

Link to article, DOI:

10.1016/j.enconman.2018.12.114

Publication date:

2019

Document Version

Peer reviewed version

Link back to DTU Orbit

Citation (APA):

Baldasso, E., Andreasen, J. G., Mondejar, M. E., Larsen, U., \& Haglind, F. (2019). Technical and economic feasibility of organic Rankine cycle-based waste heat recovery systems on feeder ships: Impact of nitrogen oxides emission abatement technologies. Energy Conversion and Management, 183, 577-589.

https://doi.org/10.1016/j.enconman.2018.12.114

\section{General rights}

Copyright and moral rights for the publications made accessible in the public portal are retained by the authors and/or other copyright owners and it is a condition of accessing publications that users recognise and abide by the legal requirements associated with these rights.

- Users may download and print one copy of any publication from the public portal for the purpose of private study or research.

- You may not further distribute the material or use it for any profit-making activity or commercial gain

- You may freely distribute the URL identifying the publication in the public portal 


\title{
Technical and economic feasibility of organic Rankine cycle-
}

\section{based waste heat recovery systems on feeder ships: impact of} nitrogen oxides emission abatement technologies

\author{
Enrico Baldasso ${ }^{a,},{ }^{*}$ Jesper Graa Andreasen ${ }^{a}$, Maria E. Mondejar ${ }^{a}$, Ulrik Larsen $^{b}$, Fredrik Haglind $^{a}$ \\ ${ }^{a}$ Department of Mechanical Engineering, Technical University of Denmark \\ Nils Koppels Allé Building 403, 2800 Kongens Lyngby, Denmark \\ ${ }^{b}$ Department of Mechanics and Maritime Sciences, Chalmers University of Technology \\ 41296 Gothenburg, Sweden \\ * Corresponding author. E-mail address: enbald@mek.dtu.dk
}

\section{Abstract}

The International Maritime Organization recently revised the regulations concerning nitrogen and sulphur oxides emissions from commercial ships. In this context, it is important to investigate how emission abatement technologies capable of meeting the updated regulation on nitrogen oxides emissions affect the performance of waste heat recovery units to be installed on board new vessels. The objective of this paper is to assess the potential fuel savings of installing an organic Rankine cycle unit on board a hypothetical liquefied natural gas-fuelled feeder ship operating inside emission control areas. The vessel complies with the updated legislation on sulphur oxides emissions by using a dual fuel engine. Compliance with the nitrogen oxide emission regulation is reached by employing either a high or low-pressure selective catalytic reactor, or an exhaust gas recirculation unit. A multiobjective optimization was carried out where the objective functions were the organic Rankine cycle unit annual electricity production, the volume of the heat exchangers, and the net present value of the investment. The results indicate that the prospects for attaining a cost-effective installation of an organic Rankine unit are larger if the vessel is equipped with a low-pressure selective catalytic reactor or an exhaust gas recirculation unit. Moreover, the results suggest that the cost-effectiveness of the 
organic Rankine cycle units is highly affected by fuel price and the waste heat recovery boiler design constraints.

Keywords: organic Rankine cycle, waste heat recovery, $\mathrm{NO}_{\mathrm{x}}$ emission abatement technologies, feeder ship, multi-objective optimization

\section{Introduction}

In the recent years, many studies aimed at investigating different approaches to reduce the amount of pollutant emissions from the shipping sector. The efficiency of a ship can be increased through a number of operational measures. For example, optimizing the ship sailing route while taking into account weather conditions can lead to a decrease of the fuel consumption [1]. A similar effect can be obtained by improving trim and draft setting, and by properly scheduling hull and propeller polishing [2]. Slow steaming, which consists in sailing at lower speeds, is also a way to decrease the fuel consumption, as the ship power consumption is roughly proportional to the cube of its speed [3]. On the other hand, the ship energy efficiency can also be increased by improving the effectiveness of individual components, such as the engine [4], the propeller [5], and the hull [6]. Sails [7] and rotors [8] can be used as additional energy sources for propulsion, while fuel cells can be used for auxiliary power generation [9]. Lastly, some of the most promising solutions focus on the utilization of the waste energy released by the main engine. As detailed in the work of Shu et al. [10], this waste heat can be effectively recovered to generate mechanical power, heating or cooling. The conversion of waste heat into mechanical power is possible through different technologies, including Rankine cycle and Kalina cycle power systems, exhaust gas turbine systems, and thermoelectric generator systems [11]. However, the conventional solution is to use a power turbine and a steam Rankine cycle (SRC) unit. The investigation carried out by Hou et al. [12] suggested that the stand-alone installation of a power turbine represents the most cost-effective solution, while the combined installation of a power turbine and an SRC unit would result in the highest possible electricity production.

An increasing number of studies are investigating the use of organic Rankine cycle (ORC) power systems as an alternative technology for marine applications [13]. The ORC operates, in principle, 
similarly to a SRC, but uses an organic compound as working fluid, leading to a higher conversion efficiency when it is used to exploit low temperature heat sources. Larsen et al. [14] compared the use of SRC, ORC and Kalina cycle power systems for waste heat recovery (WHR) on board vessels and concluded that the highest power production could be obtained by means of an ORC unit. A study carried out by Andreasen et al. [15] compared the part-load performance of a dual pressure SRC and an ORC unit designed for marine applications and showed that the ORC technology outperforms the SRC at low engine loads. The majority of previous works about the implementation of ORC units in maritime applications focused on ships using heavy fuel oil (HFO).

The shipping industry is however going through rapid changes, especially because of the legislation framework that was recently introduced by the International Maritime Organization (IMO) [16]. After the introduction of the sulphur oxides $\left(\mathrm{SO}_{\mathrm{x}}\right)$ regulation [17], some authors started to investigate the use of WHR technologies on board vessels powered by low sulphur fuels, i.e. marine gas oil (MGO) and liquefied natural gas (LNG). Soffiato et al. [18] optimized single and double pressure ORC units to use the heat from jacket water, lubricating oil and charge air cooling on board an LNG carrier and concluded that a two-stage configuration leads to the highest power production. Senary et al. [19] assessed the potential of installing a single loop SRC on board an LNG carrier and estimated that the implementation of this technology could result in a reduction of the carbon dioxide $\left(\mathrm{CO}_{2}\right)$ and nitrogen oxides $\left(\mathrm{NO}_{\mathrm{x}}\right)$ emissions by $16.9 \%$ and $36.3 \%$, respectively.

With respect to the $\mathrm{NO}_{\mathrm{x}}$ regulation [20], most works considered the Tier II limit, as it has to be met globally. However, all vessels constructed after 1 January 2016 are required to fulfil the Tier III levels when operating in $\mathrm{NO}_{\mathrm{x}}$ emission control areas (NECAs). It is therefore necessary to investigate how this constraint affects the prospects for WHR. In most of the cases, the Tier III requirements are fulfilled through the installation of emission abatement technologies that directly impact the characteristics of the main engine waste heat (exceptions are some lean burn spark ignited or some dual fuel engines [21]). The $\mathrm{NO}_{\mathrm{x}}$ abatement technologies which are currently offered for two-stroke engines are exhaust gas after-treatment based on selective catalytic reactor (SCR) technology or 
The SCR is a chemical reactor where the $\mathrm{NO}_{\mathrm{x}}$ is reduced catalytically to nitrogen and water by adding ammonia as a reducing agent. Two solutions are currently available: 1) the high-pressure SCR (HP SCR), which is placed on the high-pressure side, before the turbocharger; and 2) the low-pressure SCR (LP SCR), which is placed on the low-pressure side, after the turbocharger. The installation of a SCR unit has a direct effect on the temperature level of the exhaust gases, because it requires to keep the exhaust gas temperature, at the inlet of the SCR unit, above $280{ }^{\circ} \mathrm{C}$ to $350{ }^{\circ} \mathrm{C}$, depending on the exhaust pressure and the sulphur content in the fuel [22]. The operation with an EGR system has an even more severe impact on the exhaust system configuration. In this case, part of the exhaust gases is recirculated to the scavenge air receiver. In this way, part of the oxygen in the scavenge air is replaced by the carbon dioxide $\left(\mathrm{CO}_{2}\right)$ from the combustion process, leading to lower peak temperatures in the combustion process and therefore to a decrease in the $\mathrm{NO}_{\mathrm{x}}$ formation [22]. ORC units designed to operate with engines using the EGR technology should therefore be optimized to harvest heat from both the exhaust gases and the exhaust stream that is recirculated back to the scavenge air receiver [23]. A limited amount of previous works investigated the prospects of installing WHR units on board vessels equipped with $\mathrm{NO}_{\mathrm{x}}$ emission abatement technologies. Theotokatos et al. [24] investigated the implementation of a SRC unit on board ferries operated with an SCR unit, while Andreasen et al. [23] considered the installation of a SRC unit on board a vessel operated with an EGR unit. A previous study from Larsen et al. [25] considered, the optimization of ORC units on board vessels equipped with an EGR unit. The study was however limited to Tier II operation and did not include the possibility to harvest the waste heat from the exhaust stream recirculated to the scavenge air receiver.

The literature survey suggests that there has not yet been any study on ORC-based WHR systems utilizing heat from marine engines in Tier III compliant operation. No previous study has assessed and compared the impact of different $\mathrm{NO}_{\mathrm{x}}$ abatement technologies on the prospects for ORC-based WHR systems. Moreover, previous studies on the potential of installing WHR systems on ships did not consider the volume of the WHR system and the additional backpressure on the main engine due to the installation of the WHR boiler. There is a need to minimize the volume of the WHR system, because this will increase the cargo capacity [26]. This is especially important when the engine room 
must accommodate both the WHR system and the systems for NOx abatement. Previous studies described methods to estimate the volume of ORC power systems in various applications [27], but did not focus on the maritime sector. The only work dealing with this aspect in the maritime field is that by Rech et al. [28], who proposed a method to estimate the volume requirements for the liquid receiver of ORC units tailored for marine applications. The additional backpressure on the main engine due to the installation of the WHR boiler has a negative impact on the engine performance [29], which is generally neglected. The previous studies on this topic assessed the impact of the additional backpressure on the engine performance, but did not quantify the impact of constraining the WHR boiler pressure drop on the performance of ORC units. Mittal et al. [30] evaluated the influence of exhaust backpressure on the performance of a diesel engine, while Michos et al. [29] assessed the performance of a diesel engine as a function of the backpressure caused by the ORC unit, but did not analyse the impact of constraining the exhaust line pressure drop on the attainable ORC power output.

The objective of this paper is to identify which Tier III technology provides the more feasible conditions for an ORC-based WHR system considering the amount of energy recovered, the net present value of the investment, and the volume requirements of the ORC unit. The study focuses on feeder ships powered by two-stroke marine engines using LNG as a fuel, and considers the implementation of EGR, and low and high-pressure SCR as $\mathrm{NO}_{\mathrm{x}}$ abatement technologies. A multiobjective optimization of the ORC unit was carried with the objective functions annual electricity production, volume of the heat exchangers and net present value of the investment. The work provides primarily the following novel contributions to state-of-the-art: (i) it defines which NOx abatement technology enables the most feasible conditions for ORC-based WHR systems for ships operating in NECAs, (ii) it quantifies the impact of the limitations on the maximum engine backpressure on the ORC performance, and (iii) it estimates the ORC volume requirements as a way to assess the feasibility of installing WHR units on board vessels.

The paper is structured as follows: Section 2 explains the applied methods. Section 3 presents the results. In section 4, the results are discussed and the conclusions are outlined in Section 5.

\section{Methods}



investigated based on a selected case study, and by means of thermodynamic and economic models, as described in the following subsections.

\subsection{Case study and main engine data}

137 The study addresses the implementation of a WHR unit on board a hypothetical 2,500 twenty-foot equivalent unit (TEU) Regional feeder powered by a 10.5 MW MAN 7S60E-C10.5-GI engine [31] that operates exclusively within emission control areas (ECAs). The feeder segment merits special attention due to its main operation and contribution to air pollution in coastal zones [31]. The implementation of a dual fuel engine with a pilot flame using low-sulphur oil ensures that the $\mathrm{SO}_{\mathrm{x}}$ regulation is complied, while the use of either EGR or SCR was considered with respect to the reduction of $\mathrm{NO}_{\mathrm{x}}$ emissions. The use of the same engine operating under Tier II mode with WHR tuning was included in the study as a reference case.

The CEAS engine calculation tool from MAN Diesel \& Turbo [32] was used to obtain the engine data for the LP and HP SCR tuning. The engine data for the EGR and Tier II cases was provided by MAN Diesel \& Turbo [33]. It was assumed that the vessel is operated with LNG and low-sulphur pilot oil, and no lower limit on the exhaust gas funnel temperature was set. The minimum temperature to which the exhaust gases can be cooled is generally constrained by the fuel sulphur content in order to avoid issues related to sulphur acid corrosion in the WHR boiler [34]. The sulphur content in the fuel was here considered to be negligible. In addition, it was assumed that the vessel's heating demand could be satisfied by using the waste heat available in the jacket water and scavenge air. This results from the lower heating requirements on board LNG-fuelled ships [18] and from the use of the low-sulphur oil for the pilot flame, which does not require preheating before injection into the engine [35]. Figure 1 shows the temperature and the mass flow rates of the exhaust gas streams as a function of the main engine load for the different engine tunings. 

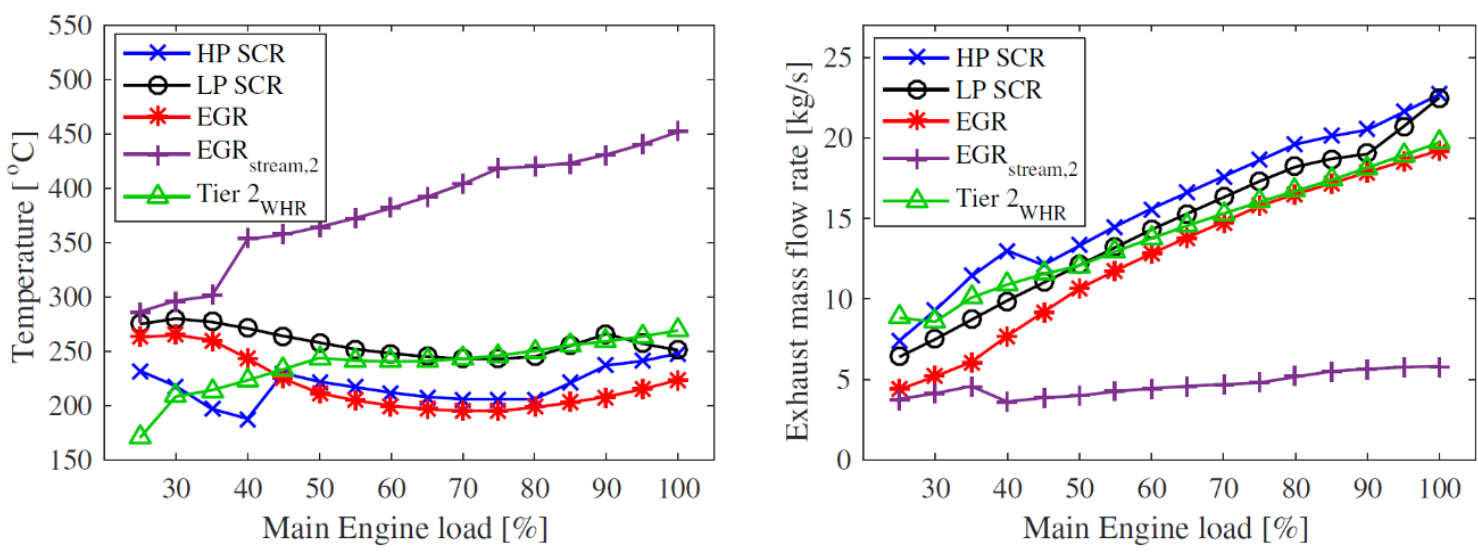

Figure 1. Temperature of the main engine exhaust gases for various engine tunings as a function of the main engine load. $\mathrm{EGR}_{\text {stream }, 2}$ represents the temperature of the exhaust stream that is recirculated to the engine scavenge air receiver $[32,33]$.

\subsection{Organic Rankine cycle configuration and working fluid selection}

Several cycle configurations have been proposed in the literature for ORC power systems tailored for WHR applications [36]. Previous studies from Dai et al. [37] and Vivian et al. [38] suggested that the implementation of a recuperator does not yield increased ORC power production when the heat source minimum cooling temperature is not constrained. Therefore, a simple non-recuperated ORC configuration was selected for this study. Figure 2 depicts the selected ORC layout. For the EGR case, the heat is harvested from the EGR recirculated stream through a heat exchanger positioned in series with the heat exchanger using the exhaust gases.

With respect to the ORC working fluids, a preselection procedure was carried out. The preselected fluids meet the following criteria: (i) commercially available [37-39]; (ii) not affected by thermal stability issues up to $230^{\circ} \mathrm{C}$; (iii) null ozone depletion potential (ODP); (iv) 100-year time horizon global warming potential (GWP) < 125; (v) National Fire Protection Association (NFPA) toxicity index $<2$. Table 1 shows the list of the preselected working fluids. The flammability and toxicity indexes were assumed according to the standard NFPA 704 [40], while the critical temperatures were obtained from Coolprop 4.2.5 [41]. The NFPA values were retrieved from Ref. [42], while the thermal degradation temperatures were retrieved from Invernizzi et al. [43] and Pasetti et al [44]. 


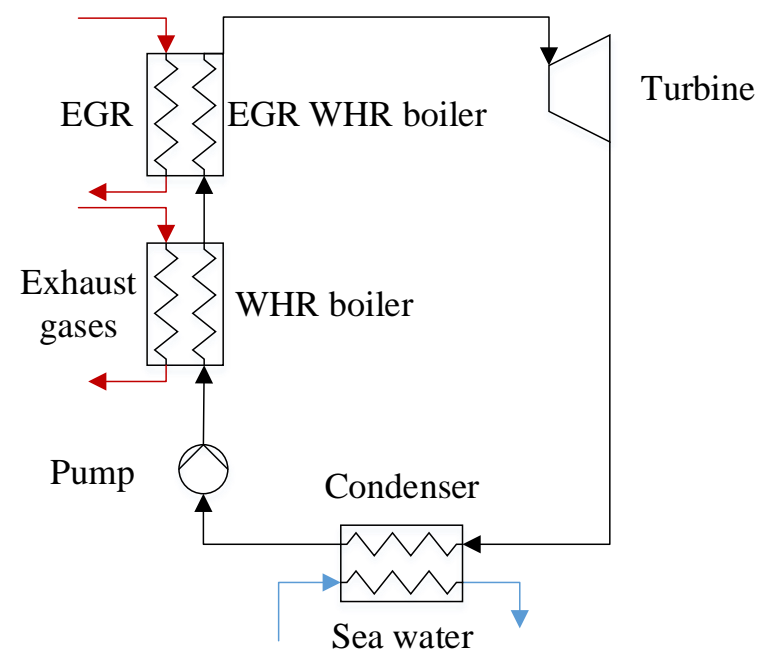

Figure 2. A sketch of the ORC unit.

174 Table 1. List of the preselected working fluids.

\begin{tabular}{|l|c|c|c|c|}
\hline Fluid & $\begin{array}{c}\mathbf{T}_{\text {crit }} \\
{[\mathbf{K}]}\end{array}$ & $\mathbf{G W P}$ & $\begin{array}{c}\text { Degradation } \\
\text { Temperature [K] }\end{array}$ & $\begin{array}{c}\text { NFPA values for } \\
\text { Flammability/Toxicity }\end{array}$ \\
\hline cyclopentane & 511.72 & $<25$ & $513-548$ & $3 / 1$ \\
\hline iso-pentane & 460.35 & $4 \pm 3$ & $500-588$ & $4 / 1$ \\
\hline n-butane & 425.12 & 4 & $563-583$ & $4 / 1$ \\
\hline n-pentane & 469.7 & $4 \pm 2$ & $573-588$ & $4 / 1$ \\
\hline $\begin{array}{l}\text { hexamethyldisiloxane } \\
(\mathrm{MM})\end{array}$ & 518.75 & 0 & 573 & $4 / 1$ \\
\hline
\end{tabular}

\subsubsection{Design conditions}

177 The ORC design model is based on the numerical model previously described in Andreasen et al.

178 [45]. The cycle net power output was calculated as follows:

$$
\dot{W}_{\mathrm{Net}}=\dot{W}_{\mathrm{exp}} \eta_{\mathrm{gear}} \eta_{\mathrm{gen}}-\dot{W}_{p}-\dot{W}_{\mathrm{p}, \mathrm{sw}}-\dot{W}_{\mathrm{bl}, \mathrm{EGR}}
$$

179 where $\dot{W}_{\text {exp }}, \dot{W}_{p}, \dot{W}_{\mathrm{p}, \mathrm{sw}}, \dot{W}_{\mathrm{bl}, \mathrm{EGR}}$ represent the power of the ORC turbine and pump, the power 180 consumption of the sea water pump and the additional power requirement in the EGR blower. The

181 latter was considered solely in the scenario of an engine equipped with an EGR unit and was estimated based on the additional pressure drop of the EGR stream in the EGR WHR boiler, which was computed assuming incompressible fluid behaviour for the exhaust gases: 


$$
\dot{W}_{b l, E G R}=\frac{\dot{m}_{\mathrm{EGR}} \Delta p_{\mathrm{EGR}}}{\eta_{\mathrm{bl}, \mathrm{EGR}} \rho_{\mathrm{EGR}}}
$$

184

185

where $\dot{m}_{\mathrm{EGR}}$ and $\rho_{\mathrm{EGR}}$ are the mass flow rate and the density of the exhaust gases recirculated in the EGR unit. $\eta_{b l}$ is the efficiency of the blower and $\Delta p_{\mathrm{EGR}}$ is the pressure drop across the EGR WHR boiler. The density of the EGR gases was assumed to be equal to the one of air at $30^{\circ} \mathrm{C}$, since the EGR blower is located after the EGR cooler, where the gas temperature is around $30{ }^{\circ} \mathrm{C}$.

When optimizing the ORC units, the maximum and minimum allowable pressures were set to $30 \mathrm{bar}$ and 0.045 bar respectively, following the indications by Rayegan et al. [46], Dresher and Brüggerman [47], and MAN Diesel \& Turbo [48]. Moreover, in order to avoid problems during operation near the critical point, the ORC unit was limited to subcritical cycle configurations with a maximum reduced pressure of 0.8 .

\subsubsection{Off-design conditions}

The main engine load is not constant during sailing and therefore an off-design model was developed to estimate the unit performance at different main engine loads. The off-design model requires as inputs the mass flow rates and temperatures of the engine exhaust streams and the ORC unit design specifications, namely, the design efficiency of the turbine, pumps and generator, and the $U A$ values (the product of the overall heat transfer coefficient, $U$, and the heat transfer area, $A$ ) of the heat exchangers. The model output is the performance of the ORC unit at off-design conditions. The offdesign performance was estimated down to a main engine load of $25 \%$, since no engine data were available for lower engine loads. The variation of the turbine isentropic efficiency was estimated using the relationship derived by Schobeiri [49] (see Equation 3), while the relationship between the mass flow rate and the pressure was assumed to be governed by the Stodola equation [50] (see Equation 4). These correlations were originally derived for multistage axial steam turbines, but as demonstrated in the Section 2.6, they can also be used with reasonable accuracy for ORC turbines.

$$
\frac{\eta_{\text {exp,is }}}{\eta_{\text {exp,is,des }}}=2 \sqrt{\frac{\Delta \mathrm{h}_{\text {exp,is,des }}}{\Delta \mathrm{h}_{\text {exp,is }}}}-\frac{\Delta \mathrm{h}_{\text {exp,is,des }}}{\Delta \mathrm{h}_{\text {exp,is }}}
$$




$$
C_{T}=\frac{\dot{m} \sqrt{T_{\mathrm{in}}}}{\sqrt{P_{\mathrm{in}}^{2}-P_{\mathrm{out}}^{2}}}
$$

$\eta$ represents the efficiency, $\Delta h$ the specific enthalpy drop, and the subscripts $\exp$, is and des refer to expander, isentropic and design conditions. The performance of the electrical generator was derived from the procedure presented by Haglind and Elmegaard [51], while the pump part-load efficiency was obtained following the method proposed by Veres [52]. Boiler (subdivided into pre-heater, evaporator and super-heater) and condenser (subdivided into de-superheater and condenser) were modelled in off-design by correcting the $U A$ values according to the variation of flow rate of the fluid dominating the heat transfer process:

$$
U A=U A_{\mathrm{des}}\left(\frac{\dot{m}}{\dot{m}_{\mathrm{des}}}\right)^{n}
$$

This equation is based on the assumption that one of the heat exchanger's sides is dominating the heat exchange process. The exponent $n$ in Equation 3 was set to 0.80 or 0.60 depending on the location of the fluid dominating the heat transfer process (inside or outside the tube banks) [53]. Table 2 shows the selected dominating heat transfer fluid and the exponent $\mathrm{n}$ for the various heat exchangers. The pressure drops at off-design conditions were assumed to vary according to the following expression [54]:

$$
\frac{\Delta \mathrm{P}}{\Delta \mathrm{P}_{\mathrm{des}}}=\left(\frac{\dot{m}}{\dot{m}_{\mathrm{des}}}\right)^{2}
$$

222

The ORC unit was operated in part load with a sliding pressure strategy and with a constant superheating temperature, as this has been shown to result in the highest power output in off-design conditions [55]. The mass flow rate of the sea water in the condenser was kept constant during operation. The ORC maximum power output was fixed to its design value in order to avoid issues related to the mechanical and thermal stresses of its components. 

exchangers.

\begin{tabular}{|l|c|r|}
\hline Heat exchanger & Limiting heat transfer fluid & Exponent n \\
\hline WHR boiler & Exhaust gases/EGR gases & 0.6 \\
\hline Condenser (two-phase) & Sea water & 0.8 \\
\hline Condenser (desuperheater) & ORC fluid & 0.6 \\
\hline
\end{tabular}

\subsection{Heat exchanger models}

The once-through-boiler (OTB) model developed by Pierobon et al. [53] with updated correlations for the estimation of the gas side heat transfer and pressure drop was used to estimate the surface area of the WHR boiler and of the EGR WHR boiler. The boiler layout is shown in Figure 3. Finned tubes were assumed in order to enhance the heat transfer coefficient on the gas side. The heat transfer coefficient inside the tubes was estimated using the Gnielinski correlation [56]. The evaporator section was discretized into 20 volumes and the heat transfer coefficient of the working fluid was assessed employing the method proposed by Shah [57], adapted for horizontal tubes. The gas-side heat transfer coefficient and pressure drop were computed using the correlations developed by ESCOA [58], which were specifically derived for WHR applications. The efficiency of the fins was computed according to the empirical correlations of Weierman [59], which account for the nonuniform distribution of the heat transfer coefficient along the fins. The pressure drops during evaporation were estimated taking into account the kinematic and viscous friction factors, which were calculated according to the relationship proposed by Friedel [60] and Rouhani and Axelsson [61], respectively.

The thermal conductivity and density of the exhaust gases were assumed to be equal to those of air at 1 bar at the average temperature in the heat exchangers. The velocities on the cold side were computed and checked to be within the limits suggested by Coulson et al. [62]. For the exhaust gases, a minimum velocity of $20 \mathrm{~m} / \mathrm{s}$ between the tube banks, and a maximum pressure drop of 0.015 bar at the maximum engine load were imposed, according to the recommendations of MAN Diesel \& Turbo [34]. By imposing these constraints the risk of soot fires in the WHR boiler, and the effect on the main 
engine performance of the additional back pressure are minimized. The minimum distance between

252 the tip of the fins in adjacent rows was set to $6 \mathrm{~mm}$ [63].

253 The volume of the WHR boiler was estimated as follows:

$$
V_{W H R, \text { boiler }}=l_{t} P_{l} P_{t}(N t p+1)(N t r+1)
$$
of this value [32].

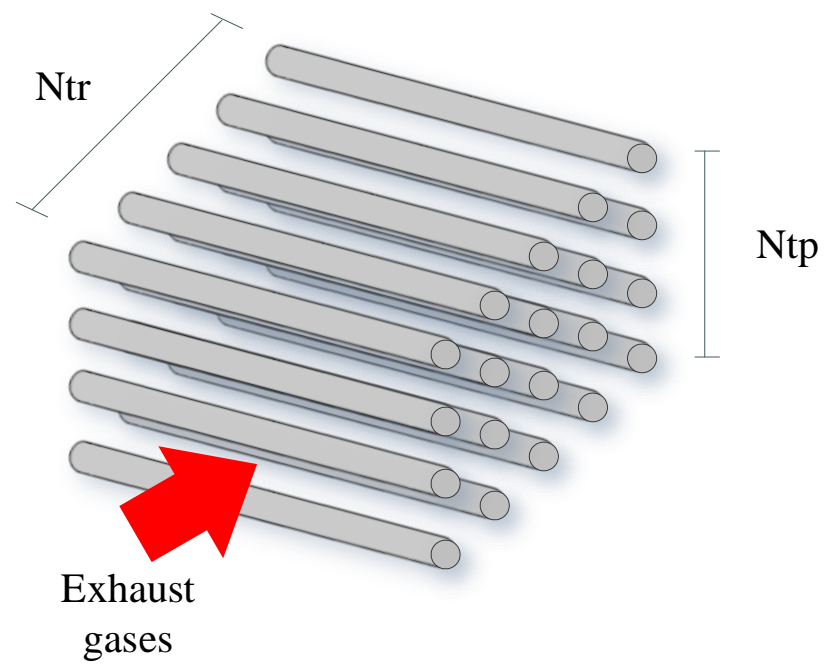

Figure 3. Layout of the WHR boiler.

261 The condenser was modelled as a shell and tube heat exchanger with shell side condensation, using the shell and tube models described in Pierobon et al. [53]. Two correlations were used for the condensation process: the approach explained in Coulson et al. [62] was used for the de-superheating part, while the procedure suggested by Kern [64] was followed to compute the heat transfer coefficient during the condensation process. The pressure drops in the single-phase region were estimated according to Coulson et al. [62], while those on the condensing side were calculated as 

computed as

$$
V_{\mathrm{ST}}=\frac{\pi}{4} d_{s}^{2} l_{t}
$$

where $d_{s}$ represents the shell diameter of the heat exchanger.

\subsection{Economic calculations}

The cost of the ORC unit was estimated using the procedure described by Turton et al. [65], which is suitable for preliminary cost estimations. This approach was initially developed for stationary chemical plants, but it has also been used for preliminary costing investigations for ORC units tailored for maritime applications [66]. Nonetheless, by using this approach the unique aspects related to the installation of ORC units on board ships (e.g. the space constraints and the need to operate in a salt water environment) are not considered. However, as the main purpose of this paper is to compare the costs of the different WHR systems rather than predicting the absolute costs accurately, it is considered to be acceptable to use this approach in this context. The overall cost of the ORC unit is given by the sum of the module costs of the various components plus the costs related to the auxiliary facilities, the contingencies and the contractor fees. It was assumed that there were no costs related to the auxiliary facilities, while the costs for the contingency and fees were assumed to account for $18 \%$ of the overall bare module cost. The bare module cost of a single component, as defined by Turton et al. [65], is the sum of the direct costs (equipment, material for installation, labour for installation) and indirect costs (freight, insurance, taxes, construction overhead, contractor engineering expenses) associated with the equipment purchase and installation. The bare module cost of a component was

$$
C_{B M}=C_{P}^{o} F_{B M}^{o}=C_{P}^{o}\left(B_{1}+B_{2} F_{M} F_{P}\right)
$$


where $C_{P}^{o}$ represents the purchasing cost of the baseline condition component (mad of the most common material, operating at ambient pressure) and $F_{B M}^{o}$ is a multiplicative factor called bare module cost factor. The latter represents a factor used to adjust the cost of the base condition component for all the previously mentioned costs, as well as for specific materials of construction $\left(F_{M}\right)$ and for the actual operating condition $\left(F_{P}\right)$. The pressure factor, $F_{P}$, was calculated using the following equation:

$$
\log _{10} F_{P}=D_{1}+D_{2} \log _{10}(P-1)+D_{3}\left[\log _{10}(P-1)\right]^{2}
$$

where $D_{1}, D_{2}, D_{3}$ are empirical constants retrieved from Turton et al. [65] and $P$ is the equipment operating pressure. The purchase $\operatorname{cost} C_{P}^{o}$ is estimated as

$$
C_{P}^{o}=K_{1}+K_{2} \log _{10}(Y)+K_{3}\left[\log _{10}(Y)\right]^{2}
$$

where $K_{i}$ represents a series of constants associated with the type of equipment being purchased and $Y$ is the capacity of the specific component. Table 3 lists the various parameters that were used to estimate the cost of the different components [65]; the bare tubes outside area was here considered for the heat exchangers. All the economic figures are expressed in US dollars. The cost correlations were provided in dollars with the value of year 2001 and then updated to dollars with the value of year 2015 by using the chemical engineering plant cost index (CEPCI):

$$
C_{t o t}\left[\$_{2015}\right]=C_{t o t}\left[\$_{2001}\right] \frac{C E P C I_{2015}}{C E P C I_{2001}}
$$

The average annual values for the CEPCIs were 397 and 556.8 in 2001 and 2015, respectively. The economic performance of the ORC units was estimated by using the Net Present Value (NPV), calculated considering a life-time of 25 years and a discount rate $(r)$ of $6 \%$ :

$$
N P V=-C_{\text {tot }}+\sum_{n=1}^{25} \frac{\text { Annual savings }}{(1+r)^{n}}
$$


The electrical load of a feeder of the type considered in the paper is around $500 \mathrm{~kW}$ and $900 \mathrm{~kW}$ at

310 port and at sea, respectively [67]. These values are larger than the net power output of the ORC (see

311 Section 3). Therefore, it was assumed that the ORC power production was used to replace the on

312 board auxiliary generators, whose average fuel consumption was estimated to be $160 \mathrm{~g} / \mathrm{kWh}$ of LNG

313 [68]. A fuel price of $12 \$ / \mathrm{mmBTU}$, representative of the average cost of European natural gas and

314 Japanese LNG in the years 2008 - 2016, was assumed [69]. The impact of the fuel price on the cost-

315 effectiveness of the unit was estimated with local sensitivity analyses. In the sensitivity analyses, the

316 LNG price was varied from $6 \$ / \mathrm{mmBTU}$ to $18 \$ / \mathrm{mmBTU}$.

317 Table 3. Equipment cost parameters used in Equations 9 and 10 [65].

\begin{tabular}{|l|c|c|c|c|c|c|c|c|c|c|}
\hline Equipment & $\mathbf{Y}$ & $\mathbf{K}_{\mathbf{1}}$ & $\mathbf{K}_{\mathbf{2}}$ & $\mathbf{K}_{\mathbf{3}}$ & $\mathbf{B}_{\mathbf{1}}$ & $\mathbf{B}_{\mathbf{2}}$ & $\mathbf{F}_{\mathbf{M}}$ & $\mathbf{D}_{\mathbf{1}}$ & $\mathbf{D}_{\mathbf{2}}$ & $\mathbf{D}_{\mathbf{3}}$ \\
\hline OTB & $\begin{array}{c}\text { Area } \\
{\left[\mathrm{m}^{2}\right]}\end{array}$ & 4.3247 & -0.303 & 0.1634 & 1.63 & 1.66 & 1 & 0.03881 & - & 0.08183 \\
\hline Cond & $\begin{array}{c}\text { Area } \\
{\left[\mathrm{m}^{2}\right]}\end{array}$ & 4.3247 & -0.303 & 0.1634 & 1.63 & 1.66 & 1 & 0.03881 & - & 0.08183 \\
\hline Turbine & $\begin{array}{c}\mathrm{W} \\
{[\mathrm{kW}]}\end{array}$ & 2.6259 & 1.4398 & - & 0 & 3.5 & 1 & 0 & 0 & 0 \\
\hline Pump & $\begin{array}{c}\mathrm{W} \\
{[\mathrm{kW}]}\end{array}$ & 3.3892 & 0.0536 & 0.1538 & 1.89 & 1.35 & 1.55 & -0.3935 & 0.3957 & - \\
& & & & & & & & & & 0.00226 \\
\hline
\end{tabular}

319 2.5. Multi-objective optimization procedure

320 The overall optimization was carried out by following the procedure described in the flowchart

321 depicted in Figure 4. 


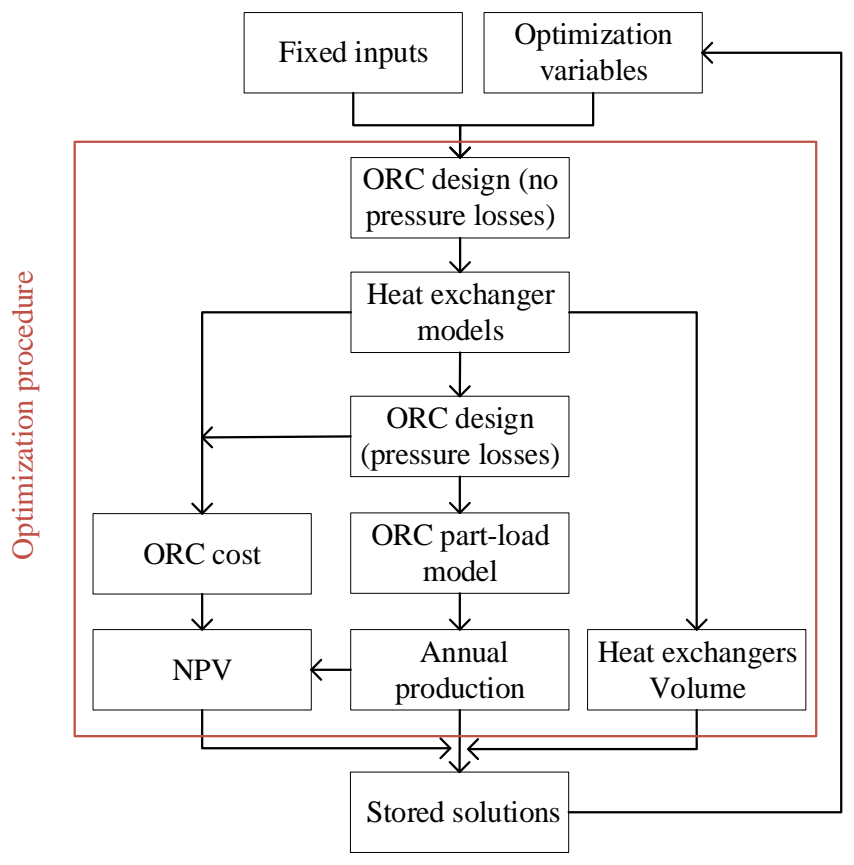

Figure 4. Sketch of the optimization procedure.

322 The fixed parameters and variables considered in the simulations are described in Tables 4 and 5 . The

323 optimization boundaries related to the geometry of the fins were selected according to ranges

324 available in ESCOA [58].

325 Table 4. Fixed parameters in the multi-objective optimization.

\begin{tabular}{|l|r|}
\hline Parameter & Value \\
\hline Electrical generator efficiency [\%] & 98 \\
\hline Gearbox efficiency [\%] & 98 \\
\hline Seawater pump efficiency [\%] & 70 \\
\hline EGR blower efficiency [\%] & 70 \\
\hline Organic Rankine cycle unit & \\
\hline Turbine isentropic efficiency [\%] & 85 \\
\hline Pump isentropic efficiency [\%] & 70 \\
\hline Once-through boiler/EGR once-through boiler & Staggered (equilateral triangle) \\
\hline Layout & Carbon steel \\
\hline Material & 48 \\
\hline Carbon steel thermal conductivity [W/ m K] & 2.0 \\
\hline Tube thickness [mm] & \\
\hline Condenser & Staggered (equilateral triangle) \\
\hline Layout & Carbon steel \\
\hline Material & 1.4 \\
\hline Tube pitch, relative to outer tube diameter [-] & 2 \\
\hline Tube thickness [mm] & 15 \\
\hline Seawater inlet temperature $\left[{ }^{\circ} \mathrm{C}\right]$ & 20 \\
\hline Seawater outlet temperature $\left[{ }^{\circ} \mathrm{C}\right]$ & \\
\hline
\end{tabular}


Table 5. Variables in the multi-objective optimization.

\begin{tabular}{|l|c|c|}
\hline Variable & Lower bound & Upper bound \\
\hline Engine load design point [\%] & 25 & 100 \\
\hline Turbine inlet pressure [bar] & 1 & 0.8 P $_{\text {crit }}$ \\
\hline ORC superheating $\left[{ }^{\circ} \mathrm{C}\right]$ & 5 & 150 \\
\hline ORC mass flow rate $[\mathrm{kg} / \mathrm{s}]$ & 2 & 60 \\
\hline Condensation temperature $\left[{ }^{\circ} \mathrm{C}\right]$ & 15 & 40 \\
\hline EGR gases outlet temperature $\left[{ }^{\circ} \mathrm{C}\right]$ & 100 & 450 \\
\hline OTB tube inner diameter $[\mathrm{mm}]$ & 21.4 & 216 \\
\hline OTB superheater tube inner diameter [mm] & 21.4 & 216 \\
\hline OTB tube length [m] & 0.6 & 7.16 \\
\hline OTB fin height [mm] & 6.4 & 31.8 \\
\hline OTB fin thickness [mm] & 0.9 & 4.2 \\
\hline OTB fin spacing [mm] & 3.6 & 25.6 \\
\hline OTB transversal pitch [mm] & 42.85 & 114.3 \\
\hline Condenser inner tube diameter $[\mathrm{mm}]$ & 12 & 46 \\
\hline Condenser tube length [m] & 0.5 & 7.5 \\
\hline Condenser baffle spacing [\%] & 20 & 200 \\
\hline
\end{tabular}

The multi-objective optimization was carried out using the genetic algorithm available in the Matlab optimization toolbox [70]. The calculations were carried out assuming that the feeder operated for 4380 hours annually and that its main engine load profile was the one shown in Figure 5. These are typical data for a feeder operating within NECAs. The annual energy production, the volume of the ORC heat exchangers and the $N P V$ were considered as the objective functions. The heat exchangers have generally the largest influence on the unit volume [27], and therefore their total volume was assumed to give an indication of ORC space requirement. The total volume ( $\left.V_{\text {tot }}\right)$ of the ORC heat exchangers was calculated as the sum of the volume of heat exchangers of the unit (the term

$V_{\text {WHR,EGR }}$ is relevant only for vessels with EGR installed):

$$
V_{\mathrm{tot}}=V_{\mathrm{WHR}, \text { boiler }}+V_{\text {cond }}+V_{\mathrm{WHR}, \mathrm{EGR}}
$$

The use of the genetic algorithm to solve complex problems generally leads to solutions close to the global optimum, yet there is no certainty that the global optimum is found for every point of the Pareto front. As a way to ensure the reliability of the results and to screen the most promising working fluids, single-objective optimizations were run in order to identify both the maximum 
energy production and $N P V$ for the various cases, using a combination of particle swarm and pattern search optimizers; both optimizers are available in the Matlab optimization toolbox [70]. It was decided to utilize evolutionary algorithms for the optimization routines based on the findings of Astolfi et al. [71], indicating their suitability to find global optima in techno-economic optimizations of ORC power systems.

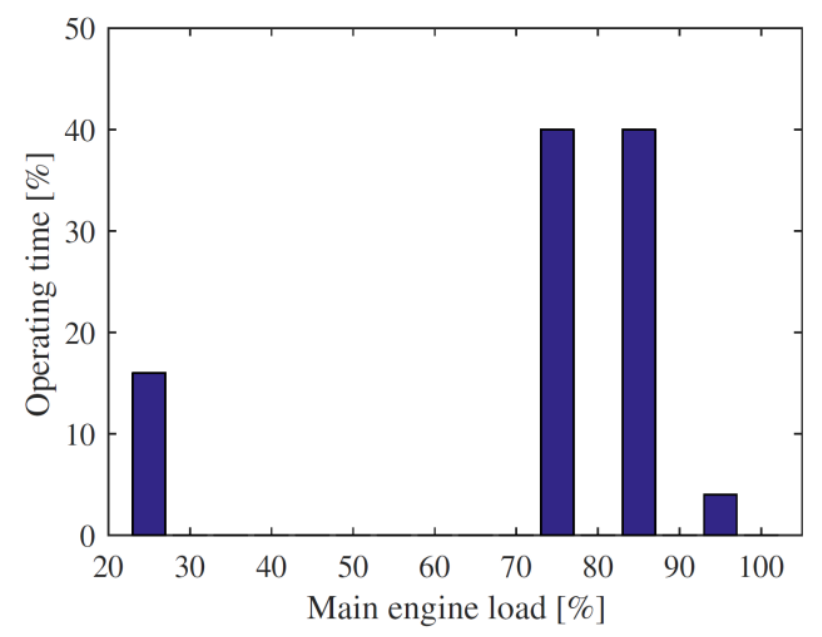

Figure 5. Typical annual engine load profile of a feeder.

\subsection{Model validation}

341 The ORC design model was previously verified both for mixtures and pure working fluids. The

342 verification, based on previous studies in literature, proved that the simulation code is able to predict

343 the cycle first and second law efficiencies with a maximum relative deviation of $3.3 \%$. Further

344 information on the validation procedure of the design model can be found in Andreasen et al. [45].

345 The accuracy of the ORC off-design model was previously assessed by comparing the numerical

346 results with the experimental data collected during the PilotORC project [72]. The comparison

347 between numerical results and operational data showed that the model was able to predict the ORC

348 power output, pressure levels and mass flow rate with an accuracy within $5 \%$. The off-design points

349 considered for validation purposes included variations in the heat source and heat sink mass flow 350 rates. Information on the validation of ORC off-design code can be found in the final report of the 351 PilotORC project [72]. 
The sizing procedure for the boiler was verified with an example from Verein Deutscher Ingenieure [73]. The relative deviations in the estimated heat transfer coefficient, and heat transfer area were $0.66 \%$ and $0.75 \%$, respectively. The estimation procedure for the gas side heat transfer coefficient was checked against the examples provided by Weierman [59], while the gas side pressure drop calculations were compared with the computational fluid dynamic (CFD) results from Mon [63]. A comparison between the results of the numerical model and CFD results from Mon [63] for 13 tube bundle geometries and 51 working conditions is shown in Figure 6. The results indicate that for most of the operating conditions the estimated pressure drops agreed with the CFD data with a relative deviation within $20 \%$. The CFD results by Mon [63,74] are considered to be reliable as they were validated by comparison with the predictions of experimental-based correlations. The sizing procedure for the shell and tube heat exchangers was compared with the example available in Coulson et al. [62]. The calculated heat transfer coefficients, overall heat transfer area and pressure drops were predicted with relative deviations within $2.6 \%, 3.6 \%$ and $3.7 \%$, respectively. The deviations are due to numerical approximations and differences related to fluid property estimations. The results of the economic estimations were compared with previously published works in literature. In particular, the estimated ORC specific costs (see Section 3.2) are in agreement with the values reported by Quoilin et al. [38] and Lemmens [75] for WHR systems in the range $200 \mathrm{~kW}$ to $1 \mathrm{MW}$. These previous studies suggested a total specific cost of around 3,000 $\$ / \mathrm{kW}$ for the installation of ORC WHR units in this capacity range. In conclusion, the results of the validations indicate that the numerical models provide results of sufficient accuracy for the objectives of the paper. 


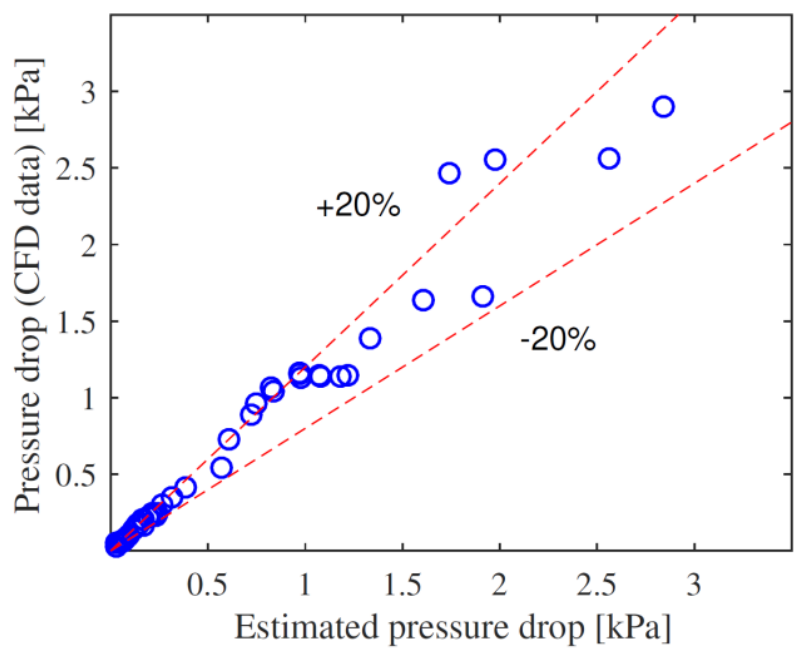

Figure 6. Comparison between the results of the numerical model and CFD results from Mon [63].

\section{Results}

354 This section shows a comparison of the performance of the pre-selected working fluid candidates, allowing the assessment of the impact of using NOx emission abatement technologies on the prospects for WHR. The comparison among the pre-selected working fluids is visualized through the results of single-objective optimizations, while the impact of emission abatement technologies on the prospects for WHR is shown by means a 2D Pareto fronts.

\subsection{Single-objective optimization and fluid selection}

The maximum annual electricity productions and net present values obtained for the various configurations are shown in Figures 7 and 8 , respectively. The estimated volumes in $\mathrm{m}^{3}$ for the ORC heat exchangers are also reported on top of the bars. The results of the single-objective optimizations suggest that both the highest electricity productions and $N P V$ could be obtained for the EGR case. The HP SCR case leads to the lowest values for both parameters. The results suggest that the highest energy productions are 1,547 MWh (butane), 1,948 MWh (iso-pentane), 2,443 MWh (cyclopentane), and $1776 \mathrm{MWh}$ (cyclopentane) for the HP SCR, LP SCR, EGR and Tier II configurations, respectively. These values correspond to $4.7 \%, 5.9 \%, 7.4 \%$ and $5.4 \%$ of the main engine annual energy production and to a reduction of the ship annual $\mathrm{CO}_{2}$ emissions of 688.4 ton, 866.9 ton, 
1,087.1 ton and 790.3 ton, respectively (assuming that the auxiliary generators' $\mathrm{CO}_{2}$ emission factor is equal to $445 \mathrm{~g} / \mathrm{kWh}[68])$.

371 The values for annual energy productions are in line with the results of Mondejar et al. [13], who

372 estimated that the installation of ORC units on board vessels powered by low sulphur fuels could lead

373 to fuel savings in the range $5.9 \%-10 \%$. The highest NPVs obtained are 158,862 \$ (cyclopentane),

374551,323 \$ (cyclopentane), 772,900 \$ (cyclopentane) and 394,570 \$ (cyclopentane) for the HP SCR,

375 LP SCR, EGR and Tier II configurations, respectively. From a fluid selection point of view, cyclopentane, n-pentane and iso-pentane show similar performances with respect to the yearly attainable fuel savings. MM shows the lowest performance in all cases and no positive $N P V$ could be attained for the HP SCR case. Cyclopentane results, as the best fluid candidate for the EGR configuration, in higher attainable energy production and $N P V$ compared to the other working fluid candidates. The estimated volumes for the ORC heat exchangers vary depending on the considered objective function and the selected emission abatement technology. The ORC configurations optimized to maximize the annual electricity production are the ones leading the highest space requirements, up to $36 \mathrm{~m}^{3}$. Conversely, smaller units are required to maximize the $N P V$. In this case, all the ORC units are estimated to have a volume between $7 \mathrm{~m}^{3}$ and $15 \mathrm{~m}^{3}$ , which corresponds to about $20 \%$ to $45 \%$ of the volume of a twenty-foot container.

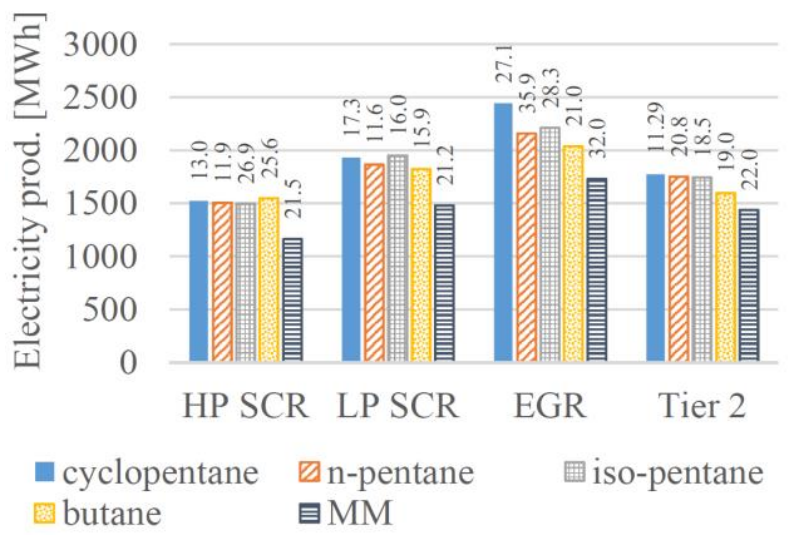

Figure 7. Maximum electricity production for the various configurations; the values above the bars represent the estimated ORC heat exchanger volumes. 


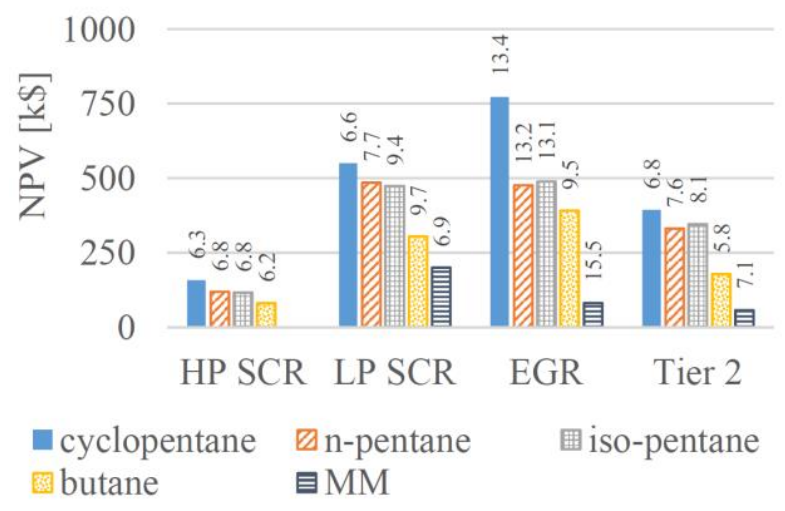

Figure 8. Maximum net present value for the various configurations; the values above the bars represent the estimated ORC heat exchanger volumes.

\subsection{Multi-objective optimization}

387 A comparison among the four considered scenarios was carried out considering cyclopentane as the working fluid as it achieved the highest $N P V$ for all three configurations. Table 6 shows the results of the multi-objective optimization procedure for the set of selected optimization variables reported in Table 5. For each configuration, the minimum, maximum, mean value and the relative standard deviation of the optimized variables are reported. A low value of the relative standard deviation means that the optimized value of the variable does not change significantly along the Pareto front. Considering the three configurations, the variables that exhibit the highest standard deviations are the ORC mass flow rate and the boiler design parameters (fin height, fin thickness and fin spacing).

Table 6. Results of the multi-objective optimization. Minimum, maximum, mean value and relative standard deviation of the optimized variables for the HP SCR, LP SCR and EGR configurations. Cyclopentane is used as working fluid.

\begin{tabular}{|l|l|l|l|l|l|l|l|l|l|l|l|l|}
\hline \multirow{2}{*}{ Parameter } & \multicolumn{4}{|l|}{ HP SCR } & MP SCR & \multicolumn{1}{l|}{ EGR } \\
\cline { 2 - 14 } & Min & Max & $\begin{array}{l}\text { Mea } \\
\mathrm{n}\end{array}$ & $\begin{array}{l}\text { RSD } \\
{[\%]}\end{array}$ & Min & Max & $\begin{array}{l}\text { Mea } \\
\mathrm{n}\end{array}$ & $\begin{array}{l}\text { RSD } \\
{[\%]}\end{array}$ & Min & Max & $\begin{array}{l}\text { Mea } \\
\mathrm{n}\end{array}$ & $\begin{array}{l}\text { RSD } \\
{[\%]}\end{array}$ \\
\hline $\begin{array}{l}\text { Engine load design } \\
\text { point }\end{array}$ & 94.4 & 99.8 & 97.7 & 2.1 & 97.5 & $\begin{array}{l}100 . \\
0\end{array}$ & 99.8 & 0.3 & 95.0 & 99.1 & 96.9 & 1.4 \\
\hline $\begin{array}{l}\text { Turbine inlet } \\
\text { pressure [bar] }\end{array}$ & 1224 & 1510 & 1442 & 5.4 & 1675 & 1709 & 1691 & 0.3 & 1175 & 2059 & 1784 & 14.1 \\
\hline $\begin{array}{l}\text { ORC superheating } \\
{[\mathrm{K}]}\end{array}$ & 6.5 & 11.1 & 8.4 & 18.9 & 8.4 & 11.5 & 9.5 & 8.3 & 7.8 & 23.6 & 18.6 & 35.6 \\
\hline
\end{tabular}




\begin{tabular}{|c|c|c|c|c|c|c|c|c|c|c|c|c|}
\hline $\begin{array}{l}\text { ORC mass flow } \\
\text { rate }[\mathrm{kg} / \mathrm{s}]\end{array}$ & 1.8 & 4.7 & 3.9 & 23.4 & 1.6 & 4.5 & 3.9 & 20.0 & 4.4 & 6.6 & 5.6 & 12.4 \\
\hline $\begin{array}{l}\text { Condensation } \\
\text { temperature }[\mathrm{K}]\end{array}$ & $\begin{array}{l}293 . \\
2\end{array}$ & $\begin{array}{l}312 . \\
0\end{array}$ & $\begin{array}{l}302 . \\
7 \\
\end{array}$ & 2.4 & $\begin{array}{l}292 . \\
8\end{array}$ & $\begin{array}{l}313 . \\
2\end{array}$ & $\begin{array}{l}303 . \\
3\end{array}$ & 2.1 & $\begin{array}{l}293 . \\
9\end{array}$ & $\begin{array}{l}322 . \\
7\end{array}$ & $\begin{array}{l}302 . \\
0\end{array}$ & 2.6 \\
\hline $\begin{array}{l}\text { EGR gases outlet } \\
\text { temperature }[\mathrm{K}]\end{array}$ & - & - & - & - & - & - & - & - & $\begin{array}{l}450 . \\
9\end{array}$ & $\begin{array}{l}487 . \\
1\end{array}$ & $\begin{array}{l}464 . \\
5\end{array}$ & 2.3 \\
\hline $\begin{array}{l}\text { OTB tube inner } \\
\text { diameter }[\mathrm{mm}]\end{array}$ & 22.6 & 23.5 & 23.2 & 1.0 & 21.4 & 23.3 & 21.7 & 2.9 & 27.2 & 35.4 & 30.1 & 10.6 \\
\hline $\begin{array}{l}\text { OTB superheater } \\
\text { inner diameter } \\
{[\mathrm{mm}]}\end{array}$ & 21.6 & 24.0 & 22.7 & 1.1 & 21.4 & 22.2 & 21.4 & 0.3 & - & - & - & - \\
\hline $\begin{array}{l}\text { OTB tube lenght } \\
{[\mathrm{m}]}\end{array}$ & 6.7 & 7.2 & 7.0 & 1.7 & 6.8 & 7.2 & 7.1 & 1.4 & 5.8 & 7.1 & 6.8 & 3.9 \\
\hline $\begin{array}{l}\text { OTB fin height } \\
{[\mathrm{mm}]}\end{array}$ & 6.4 & 8.4 & 7.0 & 4.3 & 6.6 & 8.1 & 6.6 & 9.4 & 6.5 & 7.9 & 7.0 & 6.3 \\
\hline $\begin{array}{l}\text { OTB fin thickness } \\
{[\mathrm{mm}]}\end{array}$ & 1.0 & 4.0 & 2.7 & 43.8 & 1.2 & 3.6 & 2.6 & 28.5 & 1.2 & 4.2 & 2.9 & 36.3 \\
\hline $\begin{array}{l}\text { OTB fin spacing } \\
{[\mathrm{mm}]}\end{array}$ & 3.8 & 7.0 & 5.6 & 22.0 & 4.1 & 5.4 & 4.9 & 4.0 & 3.9 & 8.3 & 6.2 & 12.9 \\
\hline $\begin{array}{l}\text { OTB transversal } \\
\text { pitch }[\mathrm{mm}]\end{array}$ & 45.8 & 51.8 & 47.3 & 2.0 & 44.6 & 50.2 & 45.0 & 1.8 & 50.4 & 60.1 & 54.4 & 6.7 \\
\hline $\begin{array}{l}\text { EGR OTB tube } \\
\text { inner diameter } \\
{[\mathrm{mm}]}\end{array}$ & - & - & - & - & - & - & - & - & 49.6 & 77.4 & 61.8 & 13.8 \\
\hline $\begin{array}{l}\text { EGR OTB } \\
\text { superheater inner } \\
\text { diameter }[\mathrm{mm}]\end{array}$ & - & - & - & - & - & - & - & - & 45.3 & 72.3 & 56.7 & 16.0 \\
\hline $\begin{array}{l}\text { EGR OTB tube } \\
\text { length }[\mathrm{m}]\end{array}$ & - & - & - & - & - & - & - & - & 1.8 & 7.2 & 4.5 & 40.9 \\
\hline $\begin{array}{l}\text { EGR OTB fin } \\
\text { height [mm] }\end{array}$ & - & - & - & - & - & - & - & - & 8.7 & 17.5 & 11.3 & 18.9 \\
\hline $\begin{array}{l}\text { EGR OTB fin } \\
\text { thickness [mm] }\end{array}$ & - & - & - & - & - & - & - & - & 1.0 & 4.1 & 1.8 & 29.2 \\
\hline $\begin{array}{l}\text { EGR OTB fin } \\
\text { spacing [mm] }\end{array}$ & - & - & - & - & - & - & - & - & 3.6 & 15.6 & 7.7 & 42.5 \\
\hline $\begin{array}{l}\text { EGR OTB } \\
\text { transversal pitch } \\
{[\mathrm{mm}]}\end{array}$ & - & - & - & - & - & - & - & - & 79.6 & $\begin{array}{l}114 . \\
3\end{array}$ & $\begin{array}{l}100 . \\
4\end{array}$ & 14.0 \\
\hline $\begin{array}{l}\text { Condenser inner } \\
\text { tube diameter [mm] }\end{array}$ & 12.0 & $\begin{array}{l}3.7 \\
\end{array}$ & 12.3 & 1.2 & 12.0 & 13.5 & 12.2 & 2.9 & 12.0 & 18.8 & 13.1 & 11.1 \\
\hline $\begin{array}{l}\text { Condenser tube } \\
\text { length }[\mathrm{m}]\end{array}$ & 2.5 & 5.4 & 3.7 & 8.8 & 3.6 & 7.3 & 4.6 & 2.1 & 3.3 & 5.2 & 4.3 & 7.8 \\
\hline $\begin{array}{l}\text { Condenser baffle } \\
\text { spacing [\%] }\end{array}$ & $\begin{array}{l}107 . \\
9\end{array}$ & $\begin{array}{l}122 . \\
9\end{array}$ & $\begin{array}{l}118 . \\
6\end{array}$ & 2.0 & $\begin{array}{l}149 . \\
0\end{array}$ & $\begin{array}{l}158 . \\
6\end{array}$ & $\begin{array}{l}154 . \\
8\end{array}$ & 1.6 & 97.0 & $\begin{array}{l}157 . \\
7\end{array}$ & $\begin{array}{l}133 . \\
7\end{array}$ & 16.4 \\
\hline
\end{tabular}

The 2D projections of the obtained Pareto fronts for the three scenarios are shown in Figure 9. The

Pareto fronts suggest that, for small volumes, the ORC annual electricity production is strongly

correlated to the volume of its heat exchangers. Units characterized by bigger heat exchangers result in higher savings, not least because with bigger heat exchangers it is possible to utilise a larger part of

403 the heat from the heat sources. Nonetheless, the relationship between the two parameters is not strictly

404 linear. After a threshold point dependent on the engine tuning and on the working fluid used, the 


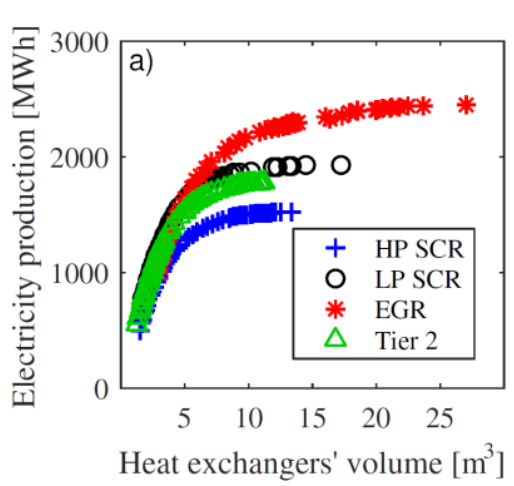

increase in heat exchanger volume required to obtain a certain increment of the annual fuel saving increases substantially. This is due to two factors: 1) the ORC power output can be increased by decreasing the heat exchangers' pinch points; 2) the required heat exchangers' heat transfer area increases to infinity when the pinch points approach zero. As shown in Figures $9 \mathrm{~b}$ and $9 \mathrm{c}$, there is a minimum value of the heat exchangers volume and annual electricity production, which enables the realization of positive net present values for the investment. If the unit is too small (resulting in low annual energy production and small volumes of the heat exchangers), the economic savings resulting from the installation of the ORC unit are not enough to pay off the investment within the expected service life. Second, the $N P V$ curves also show a maximum after which the profitability of the investment starts to decline. After the maximum point for the NPV, the annual energy production can be increased only by introducing a large increment in the volume of the heat transfer equipment.
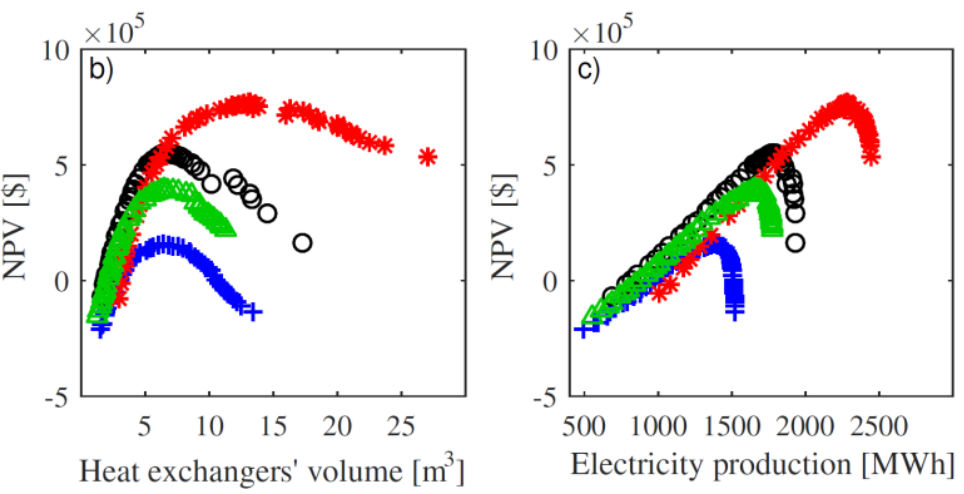

Figure 9. 2D Pareto fronts for the three considered scenarios. Cyclopentane is used as working fluid. This consideration is also consistent with the trends of the ORC specific investment cost depicted in Figure 10. At low values of ORC unit design power output, higher annual electricity productions can be obtained by increasing the design power output of the ORC unit and, similarly, higher design power outputs result in lower specific costs of the unit. Nonetheless, the ORC specific investment costs reach a minimum at a certain value of the design power $(515 \mathrm{~kW}, 514 \mathrm{~kW}, 782 \mathrm{~kW}$ and $540 \mathrm{~kW}$, respectively for the four cases), see Figure 10. This is because, after a threshold point, increased power outputs could be obtained only by using substantially larger heat exchangers. 


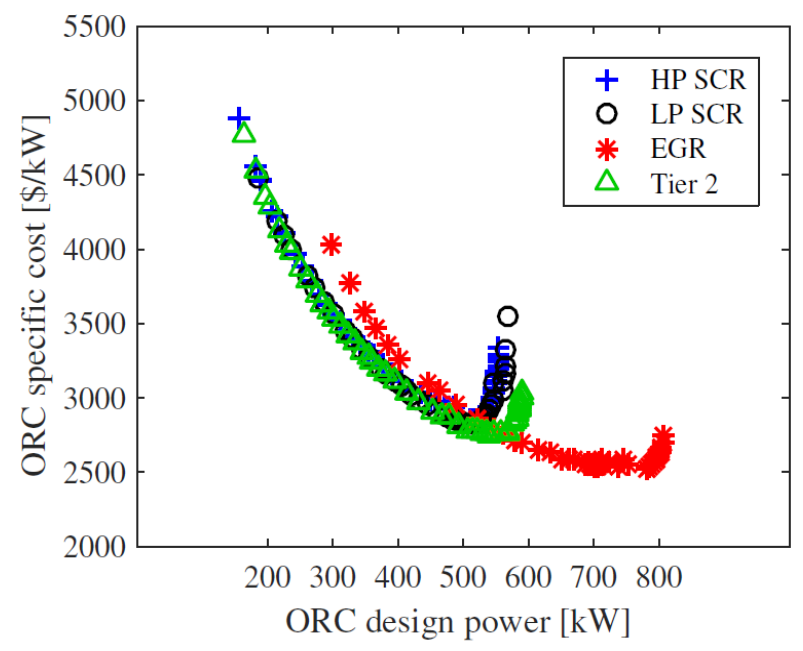

Figure 10. ORC specific investment cost for the various scenarios as a function of the design power output.

A comparison among the four scenarios suggests that the LP SCR case results in the highest NPV compared to the other scenarios, when the annual electricity production is below 1,700 MWh. The HP SCR case appears to be the least advantageous scenario in terms of both achievable fuel savings and attainable $N P V$. The EGR case, meanwhile, results in the highest $N P V$ values. Nonetheless, the optimized ORC units for the EGR scenario are the most cost-effective only when the ORC unit produces large amounts of energy and is equipped with large heat exchangers (see Figures $9 b$ and 9c). This is because the WHR boiler of the EGR ORC is sub-divided into two sections (one utilizing heat from the exhaust gases and the other from the EGR gases) and will therefore be more expensive than the WHR boiler installed on the other configurations.

Figure 11 shows the off-design performance of the three ORC configurations that led to the maximum $N P V$ in the four scenarios. The net power outputs in off-design conditions were normalized with those obtained at design conditions in order to compare the configurations. The figure indicates that the EGR and LP SCR configurations exhibit similar behaviour when the engine load decreases, except for the high ranges where the LP SCR is able to maintain an almost constant power output. The HP SCR configuration shows instead a sharp decrease of the power production, especially when the engine load is $40 \%$ to $45 \%$, and $80 \%$ to $90 \%$. This is associated with a decrease in the exhaust gas temperature at the corresponding engine loads (see Figure 1). The Tier II configuration is the one 
440 showing the poorest performance at low engine loads, due to the sharp decrease in the exhaust gases 441 temperature.

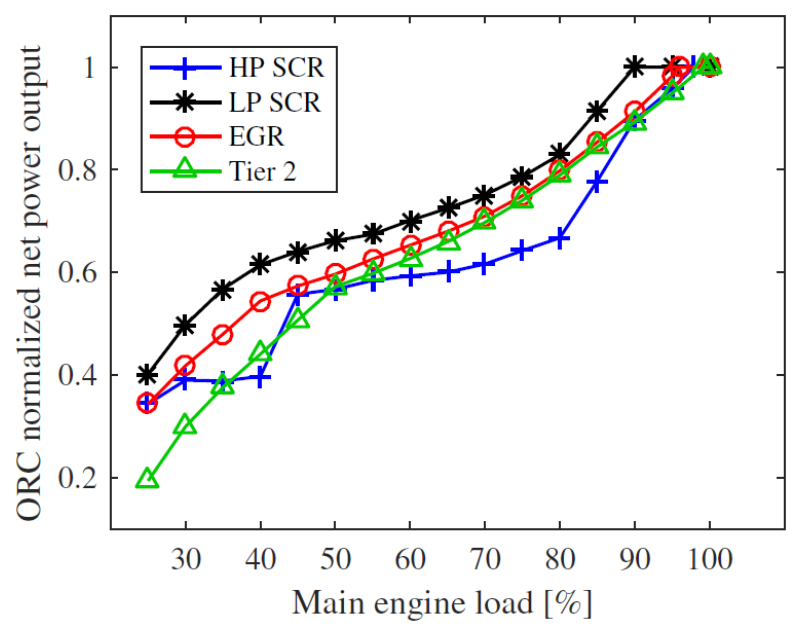

Figure 11. ORC normalized net power output as a function of the main engine load for the ORC configurations maximizing the $N P V$ in the three scenarios; cyclopentane is the working fluid used for the three scenarios.

442 Figure 12 depicts the results of the sensitivity analyses carried out to assess the impact of the fuel 443 price on the cost-effectiveness of the ORC units. The plot depicts the NPV values of the optimized 444 configurations as a function of the LNG fuel price and suggest that this parameter has a significant 445 impact on the cost-effectiveness of the units. In July 2018, the LNG price was in the range $8 \$ / \mathrm{mm}$ BTU to $10 \$ / \mathrm{mm}$ BTU [69], suggesting that the installation of ORC units would lead to positive NPVs for the LP SCR and EGR cases. 


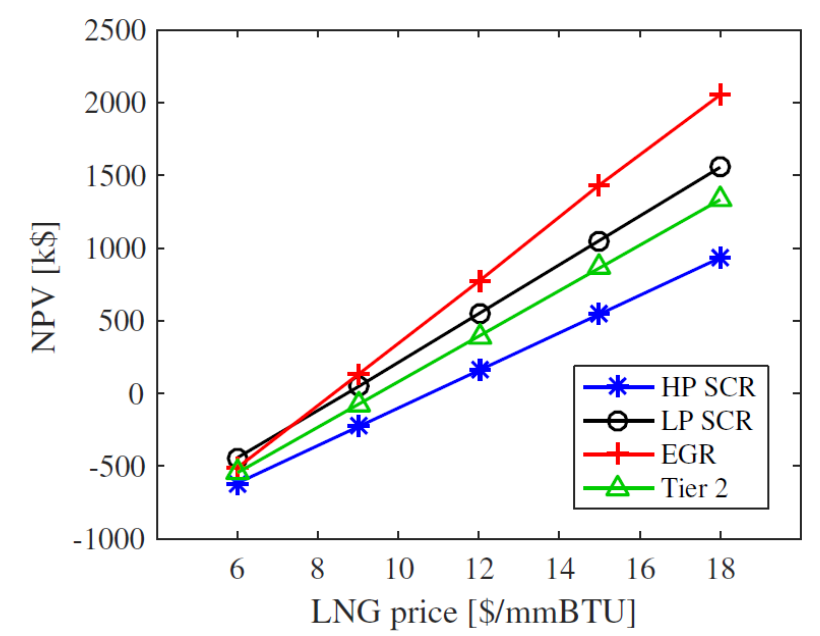

Figure 12. Sensitivity analysis: impact of the LNG price on the estimated $N P V$.

\section{Discussion}

The following subsections discuss in details the main results obtained. The main topics covered are the following: 1) impact of the selected scenario and organic Rankine cycle configuration; 2) organic Rankine cycle space requirements; 3) factors affecting the economic results; and 4) impact of the boiler design constraints on the attained results.

\subsection{Scenarios and organic Rankine cycle configurations}

The results of the multi-objective optimizations are strictly related to the characteristics of the heat sources used by the ORC units in the three selected scenarios. The temperature of the exhaust gas is the lowest when the engine is equipped with a HP SCR unit and this scenario therefore yields the lowest annual fuel savings.

In the EGR scenario, the ORC unit utilises heat from two sources, which differ both in mass flow rate and temperature. Figure 13 shows the T-Q diagram of an optimized ORC configuration harvesting heat from an engine equipped with an EGR unit. The recirculated gases in the EGR unit are at high temperatures, but have a relatively low mass flow rate. Conversely, the exhaust gases are in this case at a relatively low temperature but have higher mass flow rates. The implementation of the proposed ORC configuration featuring two WHR boilers in series is not particularly effective in recovering the 

high exergy EGR stream, resulting in high exergy destructions in the EGR WHR boiler (see Figure 13). Preliminary calculations were carried out in order to assess the benefit of implementing dual pressure ORC systems [18] but the results did not suggest substantial improvements in the ORC performance.

In any case, operating ORC units utilizing heat from both the exhaust gases and the EGR recirculated stream could result in technical challenges, including the need to install the two WHR boilers close to each other and the need to bypass the EGR WHR boiler when the EGR unit is not in operation. In addition, it should be mentioned that the EGR stream is generally cooled using a cooler spray [23] and thus the introduction of the EGR WHR boiler would likely result in significant changes in the design of the EGR unit itself. A comparison with the Tier II case suggests that the use of NOx abatement technologies, except for the HP SCR case, results in an increased potential for WHR units. This is due to the higher temperatures at which the exhaust gases are discharged after the engine turbochargers and emission abatement units.

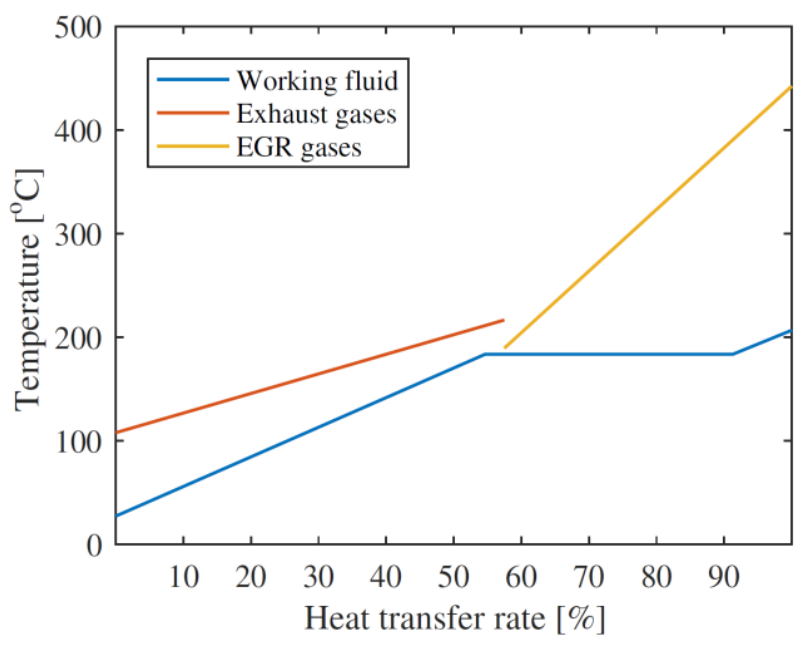

Figure 13. T-Q diagram of an optimized ORC configuration harvesting heat from an engine equipped with an EGR unit.

\subsection{Organic Rankine cycle space requirements}

The ORC space requirements were estimated by computing the volume required by the heat transfer equipment, as this generally represents the highest share of the unit space requirement [27]. In order 
to ensure that the unit is able to perform properly during transient operation, accumulators should also

483 be installed after the condenser and the boiler. The volume of these accumulators depends on the

484 dynamic events that the ORC unit is subjected to and can be estimated only through dynamic

485

486

487 simulations [28]. Such simulations are, however, beyond the scope of the present work. Furthermore, it should be noted that specific volume constraints might apply to the different ORC components in accordance with the specific location where they should be installed. As an example, the WHR boiler is generally located in the exhaust stack, while it is reasonable to install the condenser together with the other cooling systems where it is possible to pump seawater as cooling fluid. Nonetheless, the estimated volumes are lower than the space requirement for a standard twenty foot container and therefore it is expected that the installation of the ORC unit will not have a significant impact on the cargo capacity of the considered feeder ship.

\subsection{Economic considerations}

The economic performance of the ORC unit depends on three main factors: the cost of the unit, the cost of the LNG fuel and the ORC annual production. The procedure used to estimate the ORC cost is suitable for preliminary estimations. The sensitivity analyses indicated that the NPV is strongly affected by the cost of the ORC unit and the fuel price, making it challenging to give a clear answer with respect to the cost-effectiveness of WHR units for maritime applications.

One should also take into consideration that the considered feeder operates mostly at high engine loads, which means that the ORC units will perform at a high thermal efficiency. On the other hand, the considered feeder operates only 4,380 hours annually and this has a considerable impact on the annual economic savings. The implementation of ORC units on board larger container ships operating on longer routes would be more cost-effective, as they can be sailing up to 6,500 hours annually. On the other hand, larger container ships generally operate in slow steaming mode so a combined optimization of the ORC design and of the main engine tuning would have to be performed in order to maximize the efficiency of the overall system [25]. It should also be mentioned that high operational costs might arise due to the implementation of SCR units on board vessels. Yang et al. [76] estimated the annual operating expenses to be up to $150,000 \$$ for a SCR unit. These costs were not considered 
in this study, as the investigations were limited to the estimation of the economic prospects of installing ORC units in the various scenarios.

\subsection{Boiler design considerations}

In this study it was assumed that the fuel did not contain any sulphur and therefore no limitation was set on the minimum boiler feed temperature. As detailed in Andreasen et al. [15], an ORC configuration needs to include an internal recuperator and a jacket water preheater in case the sulphur content in the fuel is not negligible. In the aforementioned study, the minimum boiler feed temperature was set to $148{ }^{\circ} \mathrm{C}$ and $125{ }^{\circ} \mathrm{C}$ for a fuel with a sulphur mass content of $3 \%$ and $0.5 \%$, respectively. Another important parameter to be taken in to account is the exhaust gases dew point temperature, which was estimated to be around $50{ }^{\circ} \mathrm{C}$ for the exhaust gas composition considered in this study. The estimations were carried out with Aspen Plus [77] using the models developed by International Association for the Properties of Water and Steam [78], as presented in Wagner et al. $[79,80]$. In all the investigated scenarios, the exhaust gas temperature at the outlet of the WHR boiler was above the estimated dew point temperature, meaning that severe issues related to water condensation should not be expected. Nevertheless, local condensation of water droplets can be expected as the working fluid temperature at the inlet of the WHR boiler is lower than $50{ }^{\circ} \mathrm{C}$. This was assumed to have a negligible impact on the system operation.

Looking at the optimized designs of the Pareto fronts (see Table 6), it appears that the optimal boilers are characterized by relatively short and thick fins, with a high spacing of $6 \mathrm{~mm}$ to $9 \mathrm{~mm}$. The selection of short fins with high spacing is aligned with the findings of Mon et al. [74], who discussed how a higher ratio between the fin spacing and fin height leads to higher heat transfer coefficients and lower pressure drops. The optimized boiler geometry aimed therefore at maximizing the heat extraction with the given constraint on the air-side pressure drop. Additional simulations were carried out for the LP SCR case as a way to quantify the impact of the boiler design constraints (maximum gas side pressure drop and minimum gas velocity between the tubes) on the attainable $N P V$ values. The results of these additional optimizations suggest that relaxing the pressure drop constraint to 3 $\mathrm{kPa}$ and $4.5 \mathrm{kPa}$ would lead to a relative increment of the attainable $N P V$ by $51 \%$ and $72 \%$, 
respectively. However, in order to make a more thorough evaluation of the effects of reducing the pressure drop constraint, more comprehensive estimations need to be carried out, as an increased pressure drop on the exhaust gas side would result in an increased fuel consumption of the main engine. It would therefore be necessary to identify an optimum design of the ORC unit taking into account both the ORC and the main engine performance.

Lastly, it was estimated that allowing a minimum gas velocity of $18 \mathrm{~m} / \mathrm{s}$ and $15 \mathrm{~m} / \mathrm{s}$ would result in an increment of the attainable $N P V$ by $17 \%$ and $37 \%$, respectively. The implemented constraint in the present study of $20 \mathrm{~m} / \mathrm{s}$ comes from industry experience for HFO-fuelled vessels [34], but it is expected that lower velocity can be accepted for LNG-fuelled vessels, because of the cleaner nature of the LNG fuel.

\section{Conclusions}

The present study investigated the optimal design of cost-effective ORC units on board a hypothetical LNG-fuelled feeder vessel operating in NECA zones. Three scenarios were investigated considering different technologies to comply with the $\mathrm{NO}_{\mathrm{x}}$ legislation, including a high pressure SCR, a low pressure SCR and an EGR unit. Simulations were carried out also for the Tier II case, so to assess the impact of the emission abatement technologies on the prospects for waste heat recovery. The comparison among the scenarios was based on a multi-objective optimization procedure, as a way to evaluate the trade-off between the annual electricity production, the space required for the heat exchangers and the unit profitability, assessed by means of the 25 -year net present value.

The results of the study suggest that the implementation of an ORC unit for waste heat recovery represent a more cost-effective solution when a vessel is equipped either with a low pressure selective catalytic reactor or an exhaust gas recirculation unit, rather than when the vessel is equipped with high pressure selective catalytic reactor unit or is operated in Tier II mode. The temperature of the exhaust gases available for the organic Rankine cycle unit are lower when the feeder is equipped with a highpressure selective catalytic unit and this limits the potential for waste heat recovery with respect both to the annual electricity production and its economic advantage. The exhaust gas recirculation 
scenario leads to the highest energy production (up to $7.4 \%$ of the main engine annual energy production) and to the highest net present value $(772,900 \$)$, but results in the largest heat exchanger volumes. This results from the need to implement organic Rankine cycle units with two waste heat recovery boilers, one harvesting heat from the exhaust gases and one harvesting heat from the exhaust gas recirculated stream. In the low-pressure selective catalytic reactor scenario, the optimized organic Rankine cycle units are able to produce up to $5.9 \%$ of the main engine annual energy production with a net present value up to 551,323 US \$.

The results indicate that the economic optimum does not correspond to the design leading to the highest energy production. Above a certain threshold, dependent on the scenario and the working fluid selected, the unit annual energy production could be increased only by installing substantially larger heat exchangers leading to a decreased net present value. Furthermore, the results suggest that the cost-effectiveness of the organic Rankine cycle unit is strongly dependent on the liquefied natural gas price and the waste heat recovery boiler design constraints (acceptable additional backpressure on the main engine and minimum gas velocity between the tubes). The comparison with a vessel powered with and engine tuned for WHR and fulfilling the requirements of the Tier II regulation, suggests that the need to fulfil the Tier III regulation results in increased prospects for installing waste heat recovery units, except for the high pressure selective catalytic reactor case.

\section{Acknowledgements}

580 The research work presented in this paper was conducted within the frames of the project "Waste 581 recovery on liquefied natural gas-fuelled ships", funded by Orients Fond, Den Danske Maritime Fond and the European Union's Horizon 2020 research and innovation programme under the grant agreement no 751947 (project DYNCON-ORC). The financial support is gratefully acknowledged.

\section{References}


[2] Moustafa MM, Ali WY, Hussein AW. Energy Efficient Operation of Bulk Carriers by Trim Optimization. NAV 2015 18th Int Conf Ships Shipp Res 2015.

[3] Guan C, Theotokatos G, Zhou P, Chen H. Computational investigation of a large containership propulsion engine operation at slow steaming conditions. Appl Energy 2014;130:370-83. doi:10.1016/j.apenergy.2014.05.063.

[4] AEsoy V, Magne Einang P, Stenersen D, Hennie E, Valberg I. LNG-Fuelled Engines and Fuel Systems for Medium-Speed Engines in Maritime Applications 2011. doi:10.4271/2011-011998.

[5] Motley MR, Nelson M, Young YL. Integrated probabilistic design of marine propulsors to minimize lifetime fuel consumption. Ocean Eng 2012;45:1-8. doi:10.1016/j.oceaneng.2012.01.032.

[6] Hochkirch K, Bertram V. Hull optimization for fuel efficiency - Past, present and future. 11th Conf. Comput. IT Appl. Marit. Ind., Liege: 2012.

[7] Traut M, Gilbert P, Walsh C, Bows A, Filippone A, Stansby P, et al. Propulsive power contribution of a kite and a Flettner rotor on selected shipping routes. Appl Energy 2014;113:362-72. doi:10.1016/j.apenergy.2013.07.026.

[8] Viola IM, Sacher M, Xu J, Wang F. A numerical method for the design of ships with windassisted propulsion. Ocean Eng 2015;105:33-42. doi:10.1016/j.oceaneng.2015.06.009.

[9] Dimopoulos GG, Stefanatos IC, Kakalis NMP. Exergy analysis and optimisation of a marine molten carbonate fuel cell system in simple and combined cycle configuration. Energy Convers Manag 2016;107:10-21. doi:10.1016/j.enconman.2015.09.007.

[10] Shu G, Liang Y, Wei H, Tian H, Zhao J, Liu L. A review of waste heat recovery on two-stroke IC engine aboard ships. Renew Sustain Energy Rev 2013;19:385-401. doi:10.1016/j.rser.2012.11.034.

[11] Singh DV, Pedersen E. A review of waste heat recovery technologies for maritime 
applications. Energy Convers Manag 2016;111:315-28. doi:10.1016/j.enconman.2015.12.073.

[12] Hou Z., Vlaskos I., Fusstetter K., Kahi M. NP. New Application Fields for Marine Waste Heat Systems by Analysing the Main Design Parameters. CIMAC Congr., Vienna, Austria: 2007.

[13] Mondejar ME, Andreasen JG, Pierobon L, Larsen U, Thern M, Haglind F. A review on the use of organic Rankine cycle power systems for marine applications. Renew Sustain Energy Rev 2018;91:126-51. doi:10.1016/j.rser.2018.03.074.

[14] Larsen U, Sigthorsson O, Haglind F. A comparison of advanced heat recovery power cycles in a combined cycle for large ships. Energy 2014;74:260-8. doi:10.1016/j.energy.2014.06.096.

[15] Andreasen JG, Meroni A, Haglind F. A comparison of organic and steam Rankine cycle power systems for waste heat recovery on large ships. Energies 2017;10:1-23. doi:10.3390/en10040547.

[16] Smith T, Jalkanen J, Anderson B, Corbett J, J F, S H, et al. Reduction of GHG emissions from ships, Tech. rep. International Maritime Organization. London, United Kingdom: 2014.

[17] Sulphur oxides (SOx) Regulation 14, Tech. rep. International Maritime Organization: 2015.

[18] Soffiato M, Frangopoulos CA, Manente G, Rech S, Lazzaretto A. Design optimization of ORC systems for waste heat recovery on board a LNG carrier. Energy Convers Manag 2015;92:523-34. doi:10.1016/j.enconman.2014.12.085.

[19] Senary K, Tawfik A, Hegazy E, Ali A. Development of a waste heat recovery system onboard LNG carrier to meet IMO regulations. Alexandria Eng J 2016;55:1951-60. doi:10.1016/j.aej.2016.07.027.

[20] Nitrogen Oxides (NOx) Regulation 13, Tech. rep. International Maritime Organization: 2015.

[21] Wärtsila. The two-stroke Low-Pressure Dual-Fuel Technology: From Concept to Reality. CIMAC Congr., Helsinki, Finland: 2016.

[22] MAN Diesel \& Turbo. Emission Project Guide, MAN B\&W two-stroke marine diesel engines, 
Tech. rep. Copenhagen, Denmark: 2016.

[23] Andreasen M, Marissal M, Sørensen K, Condra T. Implementation of Exhaust Gas Recirculation for Double Stage Waste Heat Recovery System on Large Container Vessel. SIM55 55th Int. Conf. Simul. Model., Aalborg, Denmark: 2014.

[24] Theotokatos G, Livanos G a. Modern Concepts of Ferries Propulsion Plant for Reducing Fuel Consumption Cost and CO 2 Emissions. Inst Mech Eng Part M J Eng Marit Environ 2012;227:83-97.

[25] Larsen U, Pierobon L, Baldi F, Haglind F, Ivarsson A. Development of a model for the prediction of the fuel consumption and nitrogen oxides emission trade-off for large ships. Energy 2015;80:545-55. doi:10.1016/j.energy.2014.12.009.

[26] Suárez de la Fuente S, Roberge D, Greig AR. Safety and CO2emissions: Implications of using organic fluids in a ship's waste heat recovery system. Mar Policy 2017;75:191-203. doi:10.1016/j.marpol.2016.02.008.

[27] Pierobon L, Nguyen T Van, Larsen U, Haglind F, Elmegaard B. Multi-objective optimization of organic Rankine cycles for waste heat recovery: Application in an offshore platform. Energy 2013;58:538-49. doi:10.1016/j.energy.2013.05.039.

[28] Rech S, Zandarin S, Lazzaretto A, Frangopoulos CA. Design and off-design models of single and two-stage ORC systems on board a LNG carrier for the search of the optimal performance and control strategy. Appl Energy 2017;204:221-41. doi:10.1016/j.apenergy.2017.06.103.

[29] Michos CN, Lion S, Vlaskos I, Taccani R. Analysis of the backpressure effect of an Organic Rankine Cycle (ORC) evaporator on the exhaust line of a turbocharged heavy duty diesel power generator for marine applications. Energy Convers Manag 2017;132:347-60. doi:10.1016/j.enconman.2016.11.025.

[30] Mittal M, Donahue R, Winnie P. Evaluating the Influence of Exhaust Back Pressure on Performance and Exhaust Emissions Characteristics of a Multicylinder, Turbocharged, and 

Aftercooled Diesel Engine. J Energy Resour Technol 2015;137:032207. doi:10.1115/1.4029383.

[31] Regional ECOfeeder Project, Final report 2017. http://greenship.org/wpcontent/uploads/2017/04/Bilag-1-The-Regionalecofeeder.pdf (accessed January 31, 2018).

[32] MAN Diesel \& Turbo. CEAS calculation tool 2017. http://marine.man.eu/two-stroke/ceas (accessed January 31, 2018).

[33] MAN Diesel \& Turbo. Private communication 2017.

[34] MAN Diesel \& Turbo. Soot Deposits and and Fires in Exahust gas Boilers, Tech. rep. Copenhagen, Denmark: 2014.

[35] MAN Diesel \& Turbo. Operation on Low-Sulphur Fuels, Tech. rep. Copenhagen, Denmark: 2014.

[36] Lecompte S, Huisseune H, Van Den Broek M, Vanslambrouck B, De Paepe M. Review of organic Rankine cycle (ORC) architectures for waste heat recovery. Renew Sustain Energy Rev 2015;47:448-61. doi:10.1016/j.rser.2015.03.089.

[37] Colonna P, Casati E, Trapp C, Mathijssen T, Larjola J, Turunen-Saaresti T, et al. Organic Rankine Cycle Power Systems: From the Concept to Current Technology, Applications, and an Outlook to the Future. J Eng Gas Turbines Power 2015;137:100801. doi:10.1115/1.4029884.

[38] Quoilin S, Broek M Van Den, Declaye S, Dewallef P, Lemort V. Techno-economic survey of organic rankine cycle (ORC) systems. Renew Sustain Energy Rev 2013;22:168-86. doi:10.1016/j.rser.2013.01.028.

[39] Öhman H, Lundqvist P. Screw expanders in ORC applications, review and a new perspective. 3rd Int. Semin. ORC Power Syst., Brussels: 2015.

[40] NFPA 704: Standard System for the Identification of the Hazards of Materials for Emergency 
Response 2012.

[41] Bell IH, Wronski J, Quoilin S, Lemort V. Pure andPseudo-pure Fluid Thermophysical Property Evaluation and the Open-SourceThermophysical Property Library CoolProp. Ind Eng Chem Res 2014;53:2498-508. doi:dx.doi.org/10.1021/ie4033999.

[42] CAMEO Chemicals 2018. https://cameochemicals.noaa.gov/ (accessed January 31, 2018).

[43] Invernizzi, C.M., Bonalumi D. Thermal stability of organic fluids for Organic Rankine Cycle systems. In: Macchi E. AF, editor. Org. Rank. Cycle Power Syst. 1st ed., Woodhead Publishing; 2016, p. 121-51.

[44] Pasetti M, Invernizzi CM, Iora P. Thermal stability of working fluids for organic Rankine cycles: An improved survey method and experimental results for cyclopentane, isopentane and n-butane. Appl Therm Eng 2014;73:762-72. doi:10.1016/j.applthermaleng.2014.08.017.

[45] Andreasen JG, Larsen U, Knudsen T, Pierobon L, Haglind F. Selection and optimization of pure and mixed working fluids for low grade heat utilization using organic rankine cycles. Energy 2014;73:204-13. doi:10.1016/j.energy.2014.06.012.

[46] Rayegan R, Tao YX. A procedure to select working fluids for Solar Organic Rankine Cycles (ORCs). Renew Energy 2011;36:659-70. doi:10.1016/j.renene.2010.07.010.

[47] Drescher U, Brüggemann D. Fluid selection for the Organic Rankine Cycle (ORC) in biomass power and heat plants. Appl Therm Eng 2007;27:223-8. doi:10.1016/j.applthermaleng.2006.04.024.

[48] MAN Diesel \& Turbo. Waste Heat Recovery Systems (WHRS) - Marine Engines \& Systems, Tech. rep. Copenhagen, Denmark: 2014.

[49] Schobeiri M. Turbomachinery flow physics and dynamic performance. Berlin, Germany: Springer Berlin; 2005.

[50] Stodola A. Dampf- und Gasturbinen. Mit einem Anhang über die Aussichten der 
[51] Haglind F, Elmegaard B. Methodologies for predicting the part-load performance of aeroderivative gas turbines. Energy 2009;34:1484-92. doi:10.1016/j.energy.2009.06.042.

[52] Veres J. Centrifugal and axial pump design and off-design performance prediction. Tech. rep. Sunnyvale, United States of America: 1994.

[53] Pierobon L, Benato A, Scolari E, Haglind F, Stoppato A. Waste heat recovery technologies for offshore platforms. Appl Energy 2014;136:228-41. doi:10.1016/j.apenergy.2014.08.109.

[54] Lecompte S, Huisseune H, van den Broek M, De Schampheleire S, De Paepe M. Part load based thermo-economic optimization of the Organic Rankine Cycle (ORC) applied to a combined heat and power (CHP) system. Appl Energy 2013;111:871-81. doi:10.1016/j.apenergy.2013.06.043.

[55] Baldi F, Larsen U, Gabrielii C. Comparison of different procedures for the optimisation of a combined Diesel engine and organic Rankine cycle system based on ship operational profile. Ocean Eng 2015;110:85-93. doi:10.1016/j.oceaneng.2015.09.037.

[56] Gnielinski V. New equations for heat and mass transfer in turbulent pipe and channel flow. Int Chem Eng 1976;16:359-68.

[57] Shah MM. Chart correlation for saturated boiling heat transfer Equations and further study. ASHRAE Trans.; (United States), vol. 88, 1982.

[58] ESCOA. Turb X-HF Rating Instructions. Pryor, Oklahoma: 1979.

[59] Weierman C. Pressure drop calculations. In: McKetta JJ, editor. Heat Transf. Des. methods, New York: McKetta, John J; 1992.

[60] Friedel L. Pressure drop during gas/vapor-liquid flow in pipes. Int Chem Eng 1980;20:352-63.

[61] Rouhani SZ, Axelsson E. Calculation of void volume fraction in the subcooled and quality boiling regions. Int J Heat Mass Transf 1970;13:383-93. doi:10.1016/0017-9310(70)90114-6. 
[62] Coulson, J., Richardson, J., Backhurst J. Coulson and Richardson's Chemical Engineering. Oxford, UK: Butterworth-Heinemann; 1999.

[63] Mon MS. Numerical study of air-side heat transfer and pressure drop in circular finned-tube heat exchangers, Ph.D. Thesis. Technische Universitat Bergkademie Freiberg, Freiberg, Germany, 2003.

[64] Kern DQ. Process Heat Transfer. McGraw-Hill; 1950.

[65] Richard Turton, Richard C. Bailie, Wallace B. Whiting JAS. Analysis, Synthesis and Design of Chemical Processes. 3rd ed. Pearson Education; 2013.

[66] Yang MH, Yeh RH. Thermo-economic optimization of an organic Rankine cycle system for large marine diesel engine waste heat recovery. Appl Energy 2015;82:256-68. doi:10.1016/j.apenergy.2015.03.083.

[67] MAN Diesel \& Turbo. Shaft Generators for Low Speed Main Engines, , Tech. rep. Copenhagen, Denmark: 2012.

[68] Kristensen HO. Energy Demand And Exhaust Gas Emissions of Marine Engines, Tech. rep. Copenhagen, Denmark: 2012.

[69] DNV GL. Current price development oil and gas 2017. https://www.dnvgl.com/maritime/lng/current-price-development-oil-and-gas.html (accessed January 31,2018$)$.

[70] MathWorks. Official website 1994. https://mathworks.com/products/matlab.html (accessed January 31, 2018).

[71] Astolfi M, Martelli E, Pierobon L. Thermodynamic and technoeconomic optimization of Organic Rankine Cycle systems. In: Macchi E, Astolfi M, editors. Org. Rank. Cycle Power Syst. Technol. Appl. 1st ed., Woodhead Publishing 2017; 2016, p. 173-249. doi:10.1016/B978-0-08-100510-1.00007-7. 
[72] Haglind F, Mondejar ME, Andreasen JG, Pierobon L, Meroni A. Organic Rankine cycle unit for waste heat recovery on ships (PilotORC) - Final Report, Tech. rep. Department of Mechanical Engineering, Technical University of Denmark (DTU). Copenhagen, Denmark: 2017.

[73] Chemieingenieurwesen V-GV und, Ingenieure VD. VDI-Wärmeatlas: Berechnungsblätter für den Wärmeübergang. VDI-Verlag; 1991.

[74] Mon MS, Gross U. Numerical study of fin-spacing effects in annular-finned tube heat exchangers. Int J Heat Mass Transf 2004;47:1953-64. doi:10.1016/j.ijheatmasstransfer.2003.09.034.

[75] Lemmens S. Cost Engineering Techniques and Their Applicability for Cost Estimation of Organic Rankine Cycle Systems. Energies 2016;9:485. doi:10.3390/en9070485.

[76] Yang ZL, Zhang D, Caglayan O, Jenkinson ID, Bonsall S, Wang J, et al. Selection of techniques for reducing shipping NOx and SOx emissions. Transp Res Part D Transp Environ 2012;17:478-86. doi:10.1016/j.trd.2012.05.010.

[77] Aspen Plus, official website 2018. https://www.aspentech.com/ (accessed November 13, 2018).

[78] The International Association for the Properties of Water and Steam 2018. http://www.iapws.org/ (accessed November 13, 2018).

[79] Wagner W, Pruß A. The IAPWS formulation 1995 for the thermodynamic properties of ordinary water substance for general and scientific use. J Phys Chem Ref Data 2002;31:387535. doi:10.1063/1.1461829.

[80] Dittmann A. IAPWS Industrial Formulation 1997 for the Thermodynamic Properties of Water and Steam. Int Steam Tables 2008;122:7-150. doi:10.1007/978-3-540-74234-0_3. 
783 Acronyms

784 CEPCI Chemical Engineering Plant Cost Index

785 CFD Computational fluid dynamic

$786 \mathrm{CO}_{2} \quad$ Carbon dioxide

787 ECAs Emission Control Areas

788 EGR Exhaust gas recirculation

789 GWP Global warming potential

790 HEX Heat exchanger

791 HP High pressure

792 IMO International Maritime Organization

793 LNG Liquefied natural gas

794 LP Low pressure

795 MM Hexamethyldisiloxane

$796 \quad$ MGO Marine gas oil

797 NPV Net Present Value

$798 \quad$ NECAs $\quad \mathrm{NO}_{\mathrm{x}}$ Emission Control Areas

799 NFPA National Fire Protection Association

$800 \quad \mathrm{NO}_{\mathrm{x}} \quad$ Nitrogen oxides

801 ODP Ozone depletion potential

802 OTB Once-through boiler 
Mass flow rate, $\mathrm{kg} / \mathrm{s}$

Volume, $\mathrm{m}^{3}$ 
824 Greek symbols

$825 \Delta \quad$ Difference

$826 \rho \quad$ Density, $\mathrm{kg} / \mathrm{m}^{3}$

$827 \quad \eta \quad$ Efficiency

828 Subscripts and superscripts

829 BM Bare module

830 bl Blower

831 cond Condenser

832 crit Critical

833 des Design

834 EGR EGR stream

$835 \exp \quad$ Expander

836 gear Gearbox

837 gen Generator

838 in Inlet

839 is Isentropic

$840 \quad 1 \quad$ Longitudinal

841 out Outlet

$842 \mathrm{P} \quad$ Purchase

843 p Pump

844 rec Recuperator 
845 s

846 ST

847 sW

$848 \mathrm{t}$

849 tot

850
Shell

Shell and tube

Seawater

Tube/transversal

Total

Base condition 